\title{
COASTAL CHARACTER AND COASTAL BARRIER EVOLUTION IN THE BRAS D'OR LAKES, NOVA SCOTIA*
}

\author{
R. B. Taylor ${ }^{1}$ and J. Shaw \\ Geological Survey of Canada Atlantic, Box 1006, \\ Dartmouth, Nova Scotia, B2Y 4 A2
}

\begin{abstract}
Little coastal geological research has been conducted in the Bras d'Or Lakes. This is the first reexamination of the coastline since the early 1900s. The $1234 \mathrm{~km}$ of coastline is extremely varied in relief and morphology. In terms of composition, $13.5 \%$ of the shores are rock, $1.6 \%$ are artificial or human-made, and the remainder is composed of unconsolidated sediment. It is estimated that $27 \%$ of the shores are along narrow channels and embayments which are sheltered from higher wave energy, but many are low lying which makes them more vulnerable to increased flooding as sea level rises. Many of the larger coastal barriers noted in the late $19^{\text {th }}$ century remain. Using the oldest and most recent air photos and aerial video, changes at selected coastal barriers are assessed and a conceptual model for coastal barrier evolution is presented. Five natural phases of evolution were identified: (1) initiation, (2) growth, (3) establishment, (4) breakdown and (5) stranding or collapse. An alternative outcome for many barriers is artificial constraint (6), which is becoming more common as human activity increases in the Lakes. The criteria used in the model were applied to 80 of the largest coastal barriers to check its application as a guide for assessing shoreline stability. Thirty-nine percent of the barriers were identified in a building and established phase, and $44 \%$ in a breakdown to collapse phase. Field surveys are required to confirm the model and sample material for determining the age of coastal barriers and the duration of different phases of their evolution.
\end{abstract}

Très peu d'études géologiques sur les lacs Bras d'Or ont été effectuées jusqu'à présent. Cette étude constitue le premier ré-examen du littoral depuis le début du $19^{e}$ siècle. Les $1234 \mathrm{~km}$ de littoral présentent une variété très riche sur le plan du relief et de la morphologie. En effet, 13,5\% des rivages sont constitués de roche, 1,6\% sont d'origine artificielle ou dus à l'intervention humaine, et tous les autres sont composés de sédiments non consolidés. On estime que $27 \%$ des rivages se trouvent en bordure de canaux étroits et d'échancrures, ce qui les protège contre la forte énergie des vagues. Par contre, bon nombre d'entre eux sont de basse altitude, ce qui les rend plus vulnérables aux inondations lorsque le niveau de la mer s'élève. Plusieurs des grandes barrières littorales relevées à la fin du $19^{\mathrm{e}}$ siècle sont toujours présentes. Grâce à des photos aériennes d'hier et d'aujourd'hui et de vidéos aériennes, divers changements survenus à des barrières littorales sélectionnées ont pu être évalués et un modèle conceptuel d'évolution des barrières littorales a été proposé. Cinq phases naturelles d'évolution ont été identifiées : (1) initiation, (2) croissance, (3) établissement, (4) dégradation, et (5) effondrement. Une autre issue possible est la contrainte artificielle (6), qui devient de plus en plus fréquente avec une augmentation de l'activité humaine dans les lacs. Les critères utilisés dans le modèle ont été appliqués à 80 des plus imposantes barrières littorales pour vérifier leur efficacité en tant que guide d'évaluation de la stabilité du littoral. On a déterminé que trente-neuf pour cent des barrières se trouvaient dans une phase de construction et d'établissement, et $44 \%$ dans une phase de dégradation ou d'effondrement. Des études sur le terrain sont nécessaires pour confirmer le modèle et prélever des échantillons afin de déterminer l'âge des barrières littorales et la durée des différentes phases de leur évolution.

\section{Introduction}

The Bras d'Or Lakes are a semi-enclosed body of water located on Cape Breton Island, Nova Scotia. They consist of a series of elongated southwest to northeast trending basins (Fig 1) nestled between isolated hills and highlands to the north. The Lakes are connected to the Atlantic Ocean at three locations: Great Bras d'Or and Little

\footnotetext{
* Geological Survey of Canada contribution 2001033

${ }^{1}$ Author to whom correspondence should be addressed
} 
Bras d'Or Channels and through a pair of boat locks at the head of St. Peter's Inlet (Fig 1). It is estimated, using digital 1:50,000 Natural Resources Canada topographic maps, that the present length of the Bras d'Or Lakes' shoreline is $1234 \mathrm{~km}$, including $285 \mathrm{~km}$ island shores (Sherin, 1998). These shores represent $14 \%$ of the total length of the 8811 $\mathrm{km}$ of Nova Scotian coastline (Canada, 1972). The Lakes exhibit a wide variety of shore morphologies, but it was the remarkable assemblage of depositional features, primarily coastal barriers, that attracted the earliest coastal investigators. Initially Tarr (1898) and Woodman (1899) used these features to illustrate that waves, not currents, are the

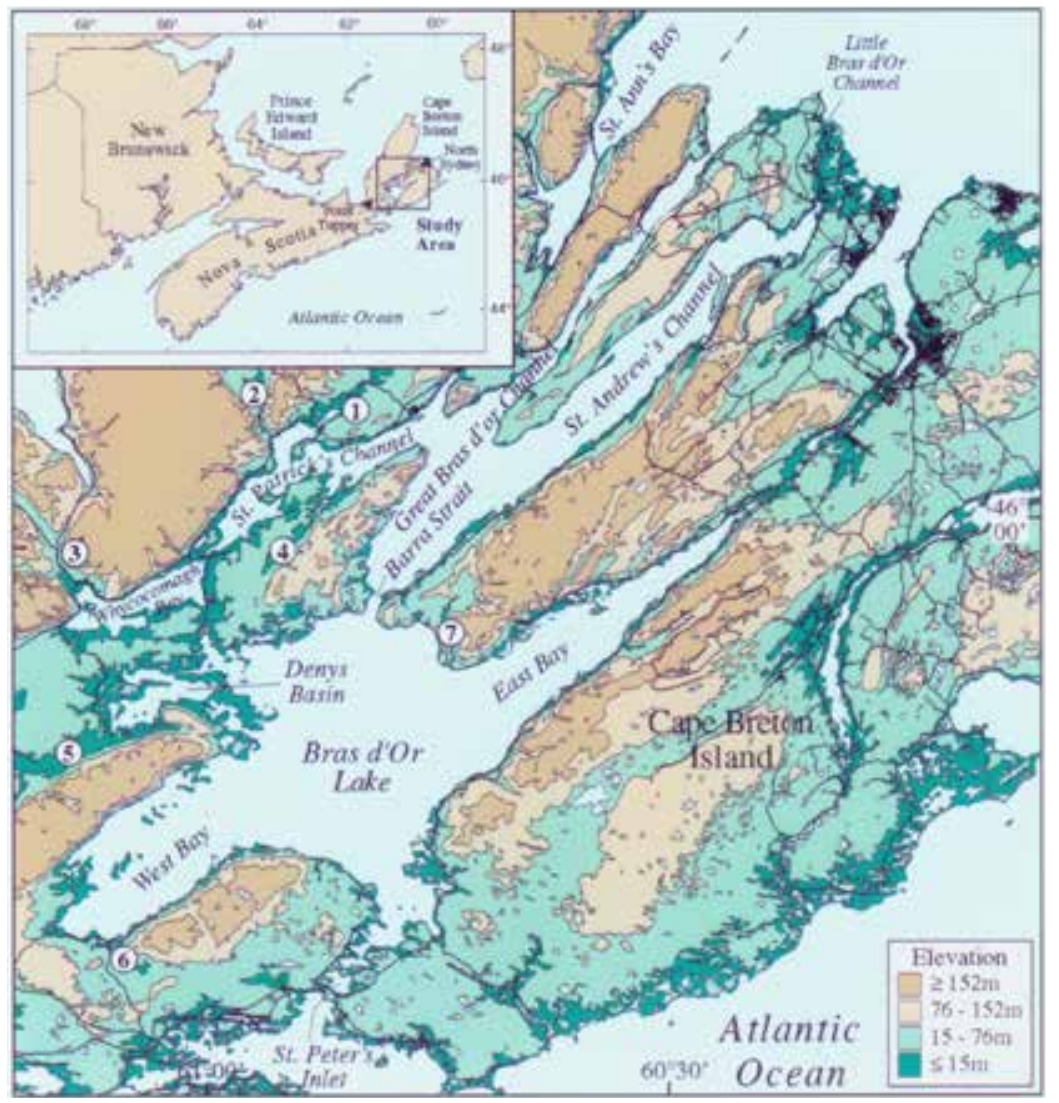

Fig 1 Location map and generalized topography of the study area illustrates the distribution of low lying and upland shores along the Bras d'Or Lakes. The topography is derived from digital 1:50,000 scale maps provided by Natural Resources Canada. Also labelled are the largest rivers emptying into the Bras d'Or Lakes including: 1) Baddeck, 2) Middle, 3) Skye, 4) Washabuck, 5) Denys, 6) Black and 7) Benacadie.

dominant force in their construction. Woodman (1899) went further and attempted to classify the different types of accumulation features (Table I). Goldthwait (1924) and Johnson (1925) used the features to illustrate their classic texts on New England and 
Atlantic Canadian coastlines. No coastal geology studies are known to have been completed in the Lakes since the early 1900s; however, there have been a number of other studies related to the coast. For example, Smith and Rushton (1964) described a number of coastal ponds or barachois in their study of potential sites for trout farming, and Grant (1994) discussed and used many shores to illustrate the glacial history of the region. Sailing guides, such as Cruising Nova Scotia (1997), provide a general description of the shores.

Table I Early classification of shore accumulation features in the Bras d'Or Lakes by Woodman (1899).

\section{1) Cusp}

(term replaced today by cuspate bar - a seaward pointing double crescentic bar formed by a single spit extending from shore and the turning back to shore or by two spits growing obliquely from the shore and converge to form a sharp cuspate form, American Geological Institute,1980).

\section{Types}

- triangular shaped lagoons

a) within a recurved spit

b) within two converging spits

\section{Examples}

Beaver Cove, St. Andrew's Ch. Dougall Point, St. Andrew's Ch. (Fig 2b, locations 67, 66)

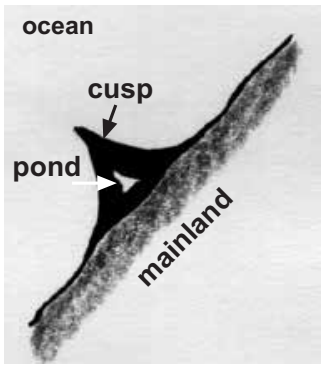

\section{2) Loop bar}

(synonym: Looped bar- a curved bar on the leeward side of an offshore island, undergoing wave erosion, formed by the union of two separate spits that have trailed off behind and joined together to form a loop that encloses or nearly encloses a body of water).

Example: Calf Island, West Bay.

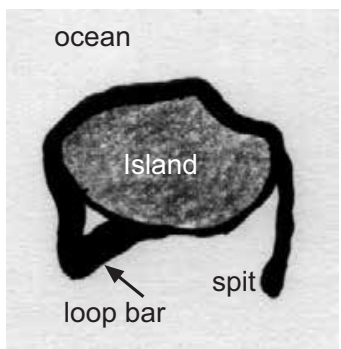

\section{3) Bay bar}

(replaced today by terms which better signify the location of the deposit such as Baymouth or Bayhead barrier).

\section{Types}

- across mouth

- across head

- damming and stream deflection

\section{Examples}

Pellier Harbour,West Bay West end St. Patrick's Channel Lochan Fad, East Bay (Fig 2b, location 16)

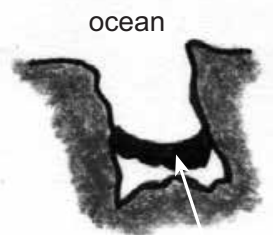

Bayhead

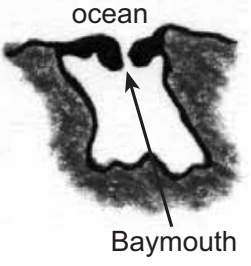


Table I (cont'd)

\section{4) Tombolo}

(a bar or barrier that connects an island with the mainland or with another island).

Types

-uncompleted

-completed -single

-double

\section{Examples}

Pringle Island, West Bay

MacLeod Point, West Bay

Indian Island, Whycocomagh Bay

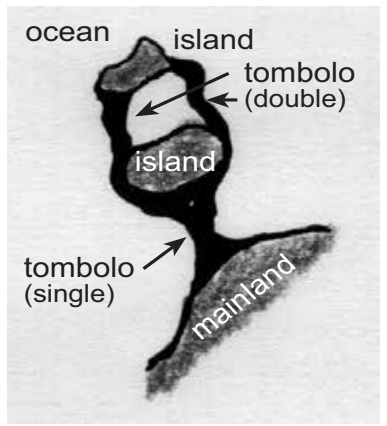

\section{5) Winged Beheadland}

(synonym: winged headland -a headland having spits extending from both sides in opposite directions).

Example: Dhu Point, East Bay

(Fig 2b, location3)

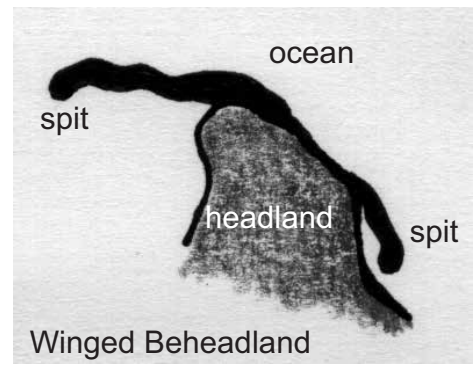

6) Delta (river) Example: Middle River, St. Patrick's Channel;

\section{7) Spit}

(a short or long point or finger-like deposit extending from shore into a body of water).

Example: Lochmore, East Bay (Fig 2b, location 15)

In June 1996 an aerial video survey provided the first continuous view of these shores (Taylor and Frobel, 1998). On the basis of the video we present an overview of the range of shore types found along the Lakes and describe some of the processes that modify these shores. A few of the larger coastal barriers reveal more about recent and historical shoreline changes are then examined. From the physical changes observed, a conceptual model of natural coastal barrier evolution is introduced. Although much of the information presented is descriptive and based on previous research outside the Lakes, the intent is to stimulate interest in these shores and in the opportunities for further research, particularly on shoreline evolution. In this paper, coastal barriers refer to spits, barrier beaches and tombolos (Table I) which are backed by water including freshwater ponds, lagoons or wetlands.

\section{Environmental Setting}

The relief and physical character of the Bras d'Or Lakes basin are the product of successive episodes of crustal uplift, erosional planation, fluvial incision, partial submergence and most recently, glacial deposition and scouring (Grant, 1994). The 
Lakes are carved out of younger, more easily eroded sedimentary rocks and the uplands consist of older, resistant, metamorphic and igneous rocks (Shaw et al., 2002). Grant (1988, 1994) and Stea et al. (1992) have mapped the surficial sediments of Cape Breton Island. In the Bras d'Or Lakes most of the shores are covered by a glacial till of unsorted debris 1-50 m thick which is finer over sedimentary rock lowlands and more bouldery in crystalline rock areas. Mounds or hills of thicker glacial deposits called drumlins form the islands in West and East Bays. These drumlins are part of a much larger field of drumlins which extends across southeastern Cape Breton Island.

There is geological evidence that sea level has been rising in the Lakes for thousands of years (Miller and Livingstone, 1993; Lynch, 1995) resulting in significant modification and reshaping of the shores. Sea level changes in the Bras d'Or Lakes are currently being reassessed (Shaw et al., 2002). The best evidence of recent trends in sea level is derived from tide gauges at North Sydney and Point Tupper located just north and south of the Lakes (Fig 1, inset). The records show a rise of 38.7 and $43.1 \mathrm{~cm} /$ century, respectively (Shaw et al., 1993, Carrera et al., 1990).

In addition to longer term geological processes which control the physical setting, the availiability of sediment for beach development and changes in sea level, it is the tides, winds, waves, and sea ice that contribute to the changes in shoreline morphology. Tides cause changes of sea level to occur over periods of about 0.5 to 1 day. Tidal range is an estimated $0.18 \mathrm{~m}$ in the central part of the Lakes; in addition water levels can be raised by $0.5 \mathrm{~m}$ above the highest predicted tide by changes in atmospheric pressure, winds and sea level variations in the Gulf of St. Lawrence that occur over periods of several days to weeks (Petrie, 1999, Petrie and Bugden, 2002).

The Lakes are renowned for their extremely rough, choppy seas which can be generated rapidly by strong winds, funnelled along the channels by the surrounding uplands. Prevailing wind direction in summer is from the southwest and stronger winds from the north-northwest dominate the fall and winter (Parkes and Gray, 1992). Wave fetch, which is the distance over water that wind can generate waves, varies from 5 to just under $50 \mathrm{~km}$. The only known recorded wave data from the Lakes were collected by Environment Canada using a wave rider buoy in the North Basin (just north of Barra Strait) from June to December 1992 and Bras d'Or Lake from June to November 1993. Wave periods were in the 2 to 4 second range and the significant wave heights (average of highest one-third of the waves) were roughly twice as large in Bras d'Or Lake as in North Basin during the periods of measurement (Petrie and Bugden, 2002). For example, for a 20 knot wind from the SW, the median significant wave height was close to $1 \mathrm{~m}$ in Bras d'Or Lake and only $0.5 \mathrm{~m}$ in the North Basin.

Based on about 30 years of sea ice data collected by Atmospheric Environment Service, Petrie and Bugden (2002) calculated weekly estimates of sea ice coverage. On average, coverage begins to develop in January although there are occasions when some ice forms in December. Ice cover begins to decrease rapidly in April and has generally disappeared by the first week in May. The most extensive sea ice cover is from late February to mid March south of Barra Strait, and slightly longer, until early April, north of Barra Strait. Ice floes from Cabot Strait can also enter Great Bras d'Or Channel as far as Seal Island during the spring (Parkes and Gray, 1992). Sea ice is often blown against the shores by strong winds causing large ice pile-ups in early and late winter. Many residents along the Lakes can provide accounts of sea ice grinding and piling against the shore, such as in 1990 when a large sheet of ice was blown southward against the shores of Middle Cape, Bras d'Or Lake (Fennell, 2001). No scientific accounts could be found which discussed the impacts of sea ice on coastal stability or infrastructure. 


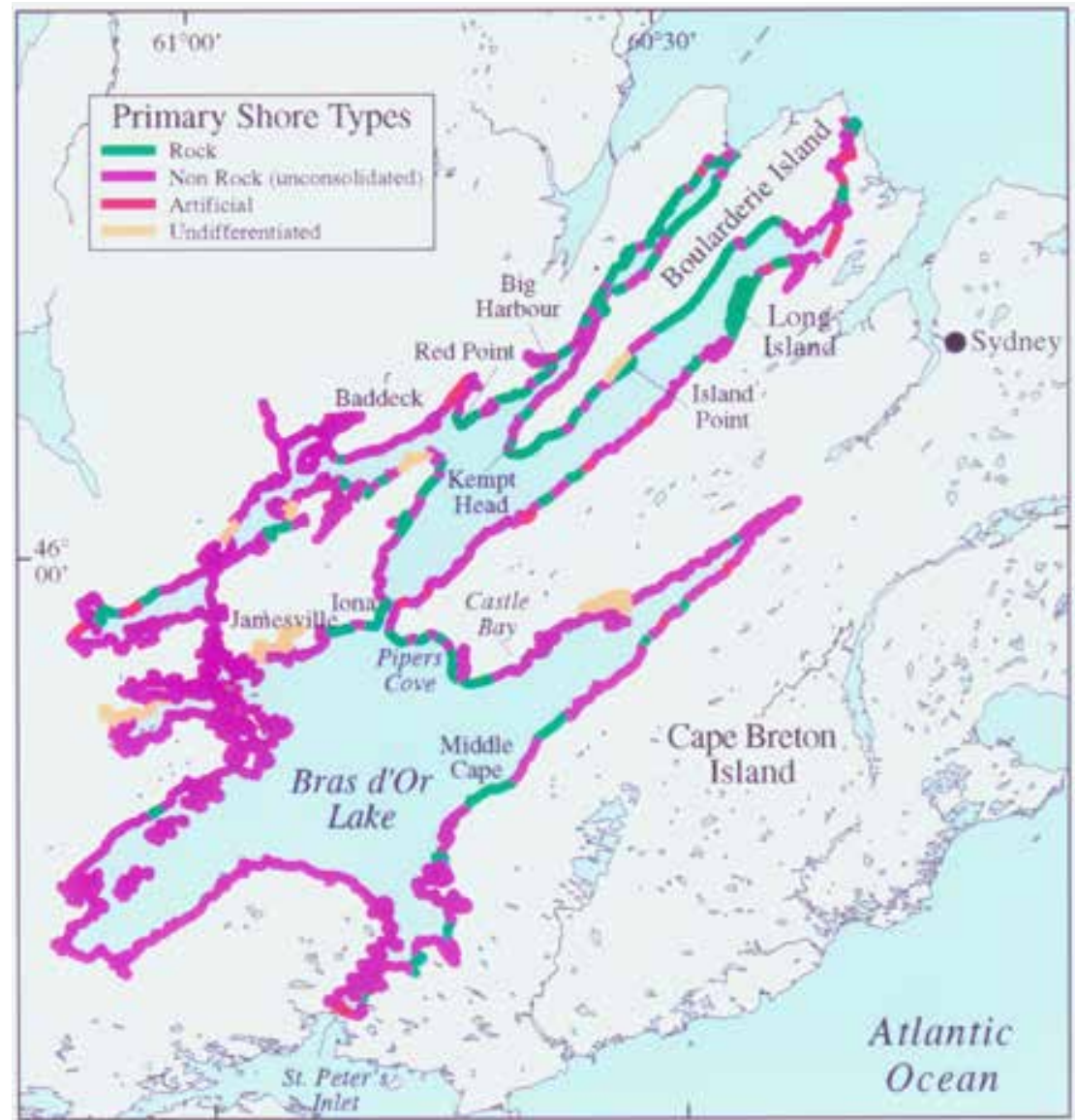

Fig 2a Distribution of primary shore types, rock, non-rock, and artificial in the Bras d'Or Lakes based on aerial video taken in 1996 (Taylor and Frobel, 1998). Shore types that could not be differentiated on the video are also shown. Only the more extensive areas of artificial shoreline, ie. road and railway beds, are illustrated. Photographs of typical shore types in the Lakes are provided in Fig 3 and 4.

\section{Coastal Character}

Coastal topography is extremely variable because of the complex underlying geology. Shores of $76 \mathrm{~m}$ or higher are found scattered throughout the Lakes (Fig 1), as are shores less than $15 \mathrm{~m}$; however, low shores are more common in western parts of the Lakes. The highest shores reach over $300 \mathrm{~m}$ along the uplands of Great Bras d'Or Channel. Although some of the low shores are cliffed, such as the peninsula at Island Point on the north shore of St. Andrew's Channel, the low shores shown on Fig 1 
indicate areas within the Lakes which would be most vulnerable to flooding as sea level continues to rise.

In terms of understanding coastal stability, it is useful to initially divide the coastline according to its composition. Using the aerial coastal video taken of the Lakes in 1996 (Taylor and Frobel, 1998), $13.5 \%$ of the shores were identified as rock, and 77 $\%$ as non-rock or unconsolidated sediment (Table II, Figs 2a, 3b, 3c). Another 1.6 $\%$ of the shores were identified as artificial fill or human-made structures (Figs 2a, $3 \mathrm{~d}$ ). Roughly $8 \%$ of the shores, mainly within the small embayments, were either not video taped or their composition could not be determined. These shores are thought to be unconsolidated.

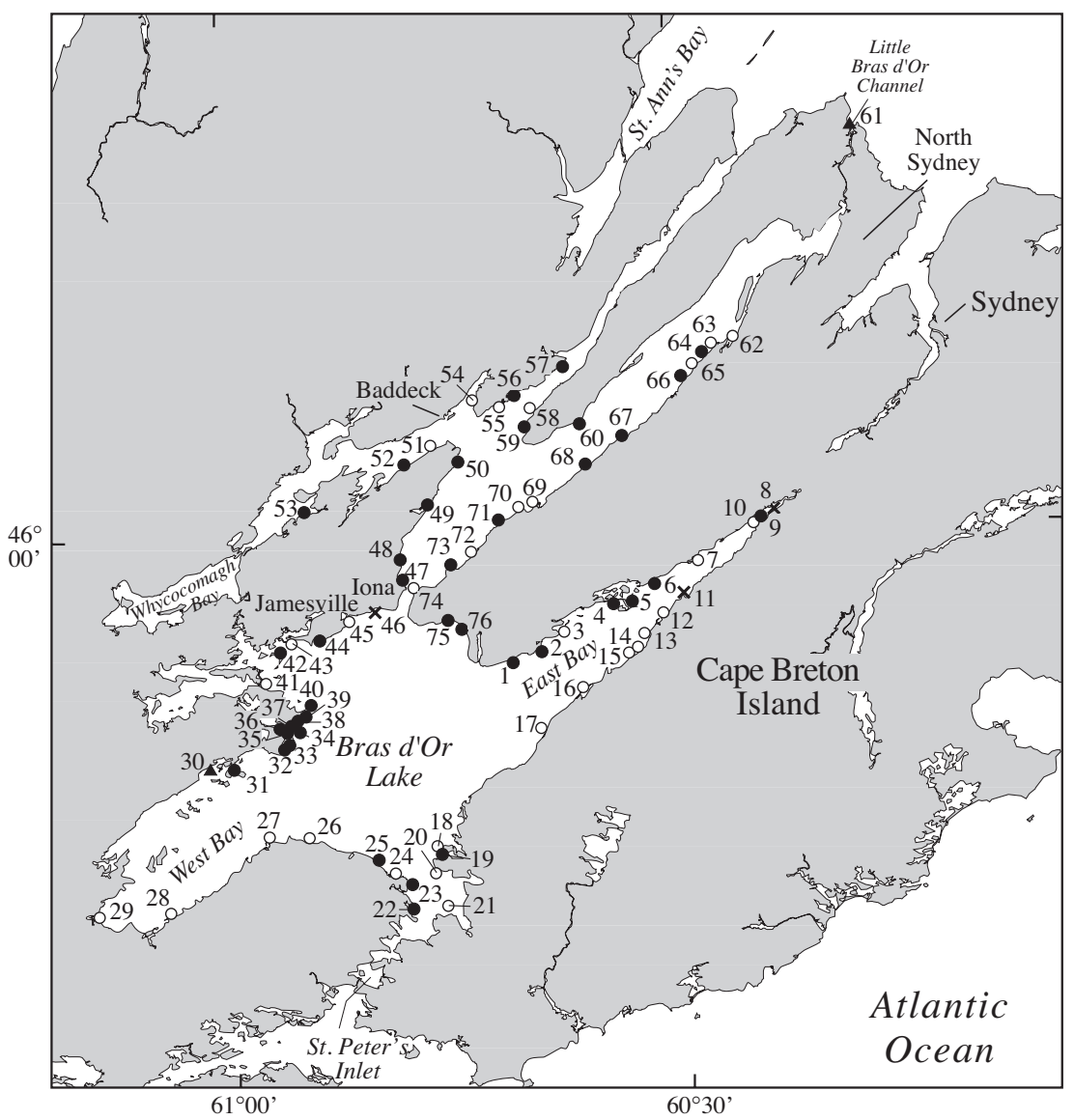

Fig $\mathbf{2 b}$ Locations of the largest coastal barriers in the Bras d'Or Lakes. The different location symbols, numbered, denote the present stage in the evolution of each barrier: building (triangle), stable (filled circle), degrading (open circle) and artificially constrained $(\mathrm{x})$. More information about the physical characteristics of each barrier is included in Appendix. 
Table II Distribution of rock and non-rock shores along the Bras d'Or Lakes and their percentage occurrence, identified from aerial video taken in 1996 (Taylor and Frobel, 1998).

\begin{tabular}{lll}
\hline Composition & Features & Coverage \\
\hline Rock Shores & cliffed and non cliffed & $13.5 \%$ \\
Non-Rock / & cliff with no beach & $10.2 \%$ \\
Unconsolidated & cliff with beach & $10.5 \%$ \\
Shores & fringing beach backed by land & $17.5 \%$ \\
& beach backed by water (coastal barriers) & $12.1 \%$ \\
Artificial Fill & vegetated shores & $26.8 \%$ \\
Undifferentiated Shores & & $1.6 \%$ \\
& & $7.8 \%$ \\
& & Total \\
\hline
\end{tabular}

Rock Shores Rock shores are concentrated along the upland shores of Great Bras $d^{\prime}$ Or and St. Andrew's Channels, the north shore of Bras d'Or Lake and south shore of East Bay (Fig 1, 2a). The physical character of these shores is closely correlated with the local bedrock and its resistance to erosion. The highest backshores $(76 \mathrm{~m})$ exist in
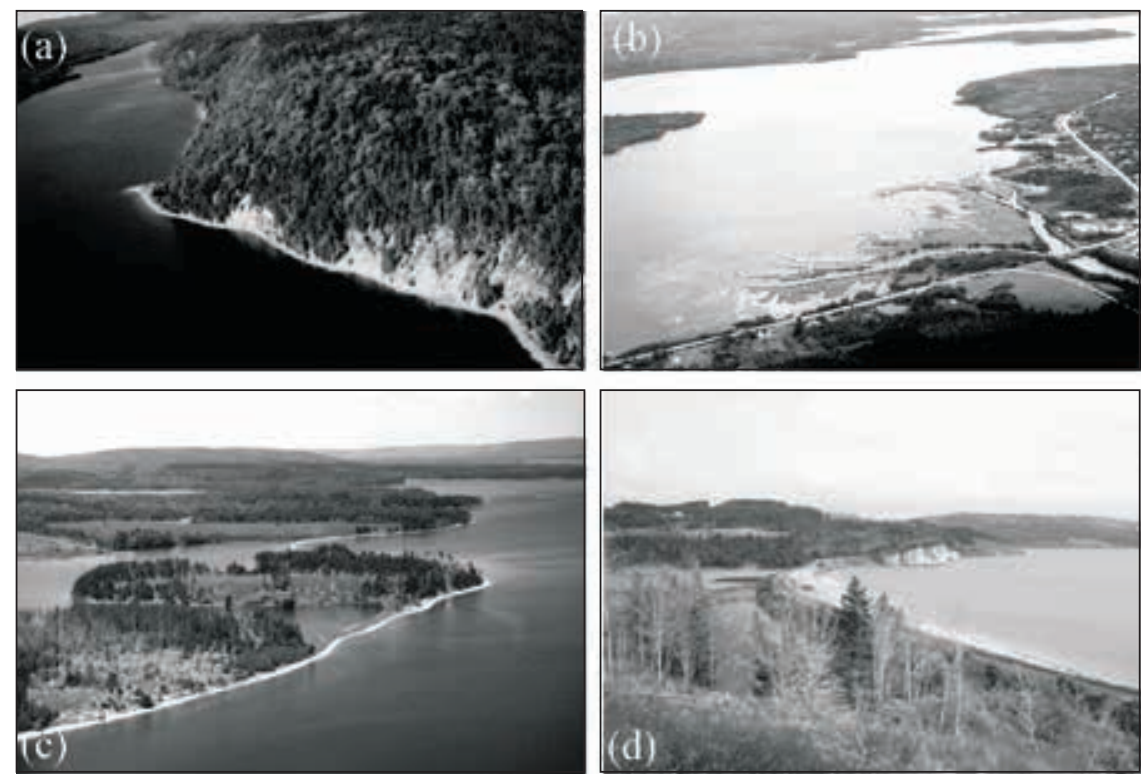

Fig 3 Photographs of select shore types in the Bras d'Or Lakes (a) Rock: 60 m high shores of Long Island, St. Andrew's Channel (June 25, 1996); (b) Non-rock: the Middle River delta, Nyanza Bay (Sept. 9, 1992), with extensive, partially submerged floodplain; (c) Non-rock: drumlin headlands and interconnecting barrier beaches representative of many low shores, Pellier Island (June 24, 1996) and (d) Artificial: fill added to build a railway line across an older barrier beach near Jamesville (Nov. 21, 2000). 

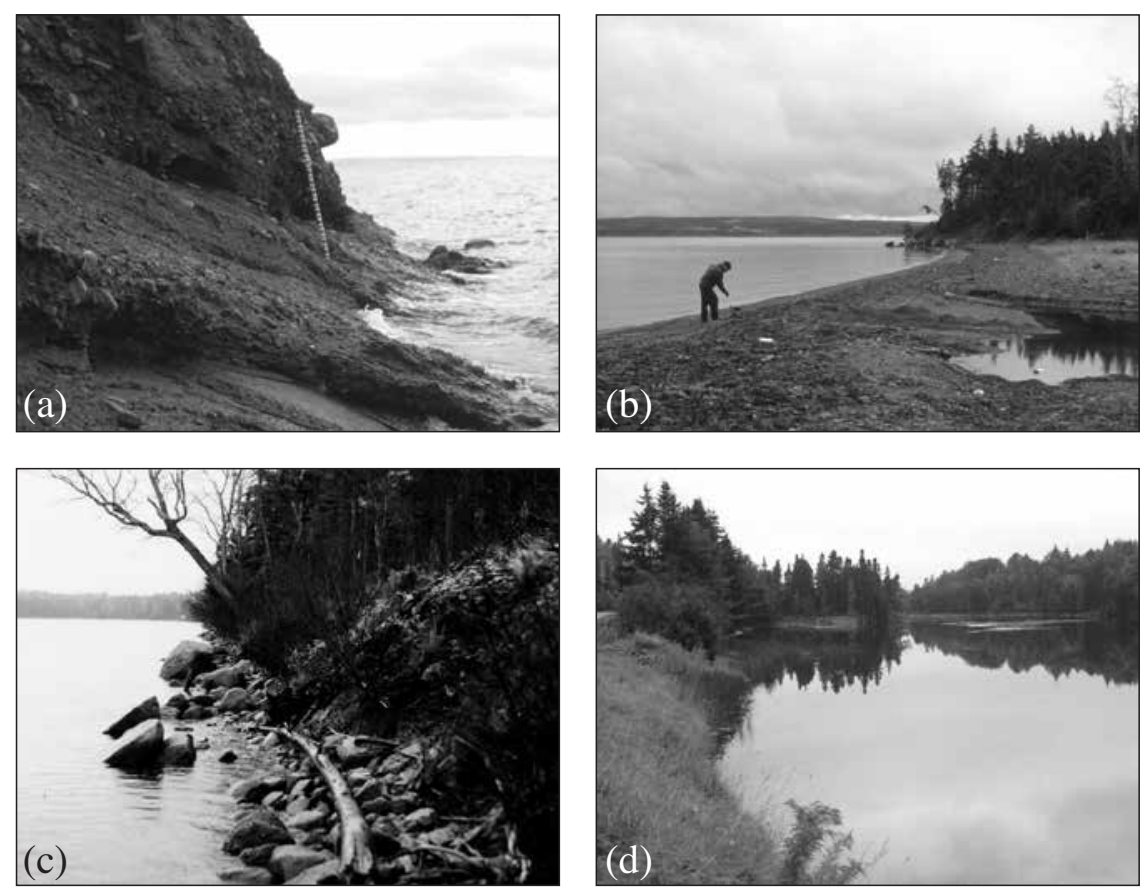

Fig 4 The composition of the shoreline varies from rock outcrop (a) such as well defined intertidal ramps cut into conglomerate rocks along Pipers Cove (Nov. 21, 2000); and unconsolidated shores such as (b) better sorted sand beaches at Grass Cove where the inlet was closed by waves from the NE or (c) poorly sorted boulder lag along outer Cow Bay, St. Patrick's Channel (Nov. 21, 2000) and (d) vegetated shores in the small embayments such as Campbells Cove, where fetch is insufficient to develop wave-built shore features (Sept. 7, 1998).

areas of the oldest and most resistant rocks: granites in the north and volcanics in the south. The most notable granite cliffs are at Red Point, near Baddeck. Long Island, St. Andrew's Channel which consists of older Proterozoic non-granitic rocks is fringed by $60 \mathrm{~m}$ high, talus banked cliffs (Figs 2a, 3a). The volcanic rock shores, along East Bay and St. Peter's Inlet are mostly low lying, except for the upland coast near Middle Cape (Fig 2a). Along much of these shores the bedrock is masked by glacial deposits but when exposed, rugged, irregular outcrops trap sediment and form small pocket beaches.

The best examples of younger clastic rock cliffs are along Pipers Cove, Bras d'Or Lake where well defined shore ramps (Figs 2a, 4a) are backed by cliffs of 15 to $20 \mathrm{~m}$. Both the ramps and cliffs are cut in seaward dipping conglomerate rock, topped by glacial deposits. Near Benacadie Point the bedrock is similar but shore ramps do not form because of a change in bedding orientation. The most common shore cliffs observed in the Lakes are usually less than 15 m elevation, formed in Windsor Group rocks consisting of gypsum, anhydrite, sandstone, limestone or shale. Exposures of gypsum anhydrite form distinctive white shore cliffs along several shores including between 
Jamesville and lona, Bras d'Or Lake (Figs 2a, 3d), along Island Point, St. Andrew's Channel, and Big Harbour, Great Bras d' Or Channel. Solutional weathering of the upper slopes and sink holes are associated with these outcrops. Well developed shore cliffs composed of Horton group rocks mark Kempt Head at the south end of Boularderie Island (Fig 2a) and low cliffs constrain Little Bras d'Or Channel. In terms of shoreline evolution, high rock shores limit lake expansion and rock outcrops provide anchor points and a source of sediment for the large depositional shore features.

Non-rock shores Despite the presence of higher inland terrain, much of the shoreline is low lying and composed of unconsolidated sediment of mainly glacial origin. The non-rock shores can be further broken down into five subdivisions on the basis of their morphology and beach development (Table II). Thicker glacial deposits form coastal headlands and shore cliffs which are important sources of sediment and anchors for beach development. Roughly $20 \%$ of the shores were cliffed, with half being fronted by mixed sediment beaches (Fig 3c). Many of the cliffed shores are erosional scarps less than $5 \mathrm{~m}$ high. The higher shore cliffs are eroded drumlins or localised cliff sections composed of multiple glacial tills or other deposits such as the $30 \mathrm{~m}$ high cliffs near Castle Bay, East Bay.

Forty percent of the shores are beaches of which $12 \%$ are defined as coastal barriers (Figs 2b, 3c, 4b) backed by water. Many beaches appear at first glance to be sandy but most contain a mixture of sand to cobble size material and in many cases the presence of dune vegetation is associated with both sand and very fine pebble. Coastal barriers $250 \mathrm{~m}$ or longer are located numerically on Fig $2 \mathrm{~b}$ and described in Appendix 1. Several are discussed in more detail in the remainder of the paper.

Another $27 \%$ of the shores, mainly within the embayments exhibit little evidence of wave-built beach features, and vegetation extends to the waterline. Along the north shore of St. Patrick's Channel many of the forested and grassed slopes are fringed by a boulder lag (Fig 4c) formed by the winnowing of glacial deposits by water motion. Vegetated shores exist mainly within small, or narrow embayments (Fig 4d). The largest extent of wetland and marsh shores are within Denys Basin, and head of Whycocomagh Bay. Extensive wetland and marsh vegetation cover the floodplains and deltas at the mouths of the Skye, Middle, Baddeck, Denys, Washabuck, Black and Benacadie Rivers (Figs 1, 3b). The deltas extend beyond the main shoreline at the Skye, Middle and Baddeck Rivers and exist well back of the main shoreline at the Denys, Black and Benacadie Rivers. Drowning of the river floodplains may be an indicator of rising sea level, however research into the dynamics and sedimentation of these rivers is required to confirm it.

Artificial shores include human-built structures such as wharves, jetties and breakwalls, and fill along road and railway lines (Fig 2a, 3d). These deposits or structures are designed to protect the shores from erosion and therefore are more resistant to change. The scale of the map in Fig 2a precludes showing individual shore structures so only the more extensive areas of fill are shown.

\section{Coastal Barriers: Evidence of Coastal Changes}

Much has been written recently regarding the evolution of coarse grained beach deposits found along the outer coast of Nova Scotia (Boyd et al., 1987; Forbes and Taylor, 1987; Forbes et al. 1990, 1995; Carter et al., 1990; and Orford et al., 1991). Similar shore features, such as spits, barrier beaches and tombolos are found in the Bras $d^{\prime}$ Or Lakes (Fig 2b). Their horizontal extent is comparable to features observed on the 


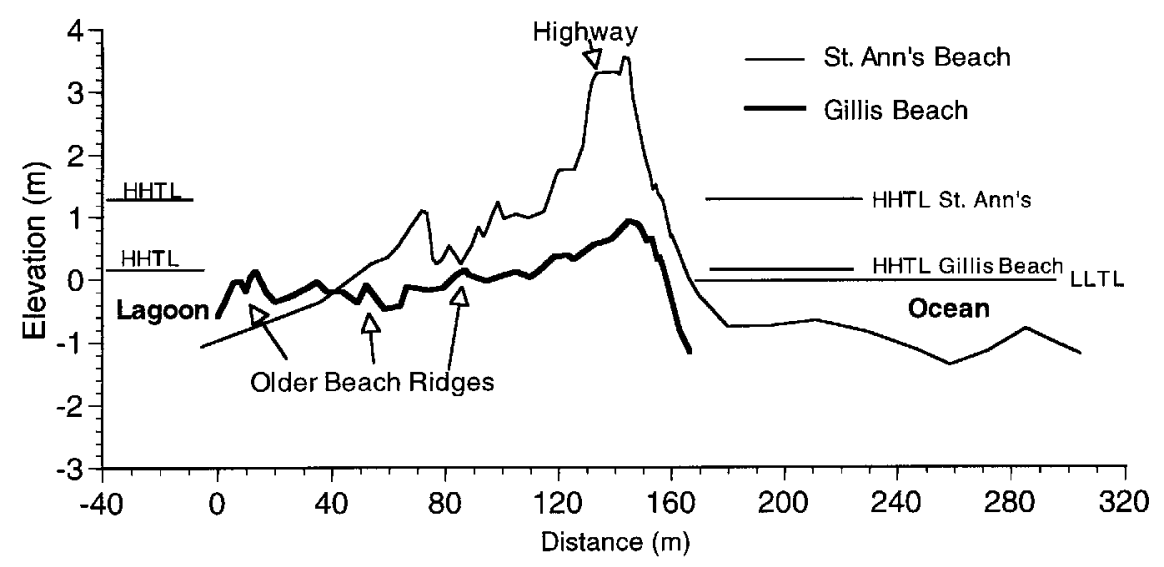

Fig 5 Cross-shore profiles of coastal barriers from St. Ann's Bay, on the outer Nova Scotia coast (Fig 1), and Gillis Beach, Bras d'Or Lake, illustrate the difference in vertical extent of beach features in the two areas. The large tidal range is $1.34 \mathrm{~m}$ at St. Ann's (Canadian Hydrogeographic Service, 2000) and $0.18 \mathrm{~m}$ in Bras d'Or Lake (Petrie and Bugden, 2002). The difference between the seaward beach crest elevations is $2.3 \mathrm{~m}$. Both barriers are backed by submerged beach ridges. Vertical datum for both beaches is set at lower low tide level (LLTL). HHTL is higher high tide level. (St. Ann's Beach survey data are courtesy of D.L. Forbes and D. Frobel, GSCA).

Atlantic coast of Nova Scotia but their vertical scale is much smaller because of significant differences in the magnitude of processes affecting them (Fig 5). A smaller tidal range, lower wave energy and longer duration of sea ice exist in the Lakes.

In his early description of Bras d'Or Lakes shores, Woodman (1899) provided a preliminary classification of coastal depositional features based primarily on morphology (Table I). Many of the names he used to describe the features have changed and evolved, as has our understanding about the evolution and linkage of different shore features. All of the depositional features cited by Woodman (1899), including those listed in Table I, are still present in the Lakes 100 years later (Fig 2b), but some have changed significantly. Even within the same geographic area, where the shores were subject to similar wave energy, significant differences in shoreline change were observed (Fig 6).

Very little research has been completed on coastal barriers within the Lakes and much field work is required before a detailed chronology of their evolution can be achieved. Nevertheless, the number, sequence and arrangement of beach ridges within each depositional complex reveal much about its recent evolution. For example, multiple beach ridges signify sediment abundance and shoreline progradation. Low, discontinuous ridges reveal a scarcity of sediment and shoreline degradation. Furthermore we can differentiate between drift-aligned barriers, where waves strike the coast at an oblique angle moving sediment alongshore, and swash-aligned systems where waves strike more directly onshore and move sediment onshore and offshore. Swash-aligned barriers tend to be more concave in shape and build across embayments. Drift-aligned barriers are more straight to convex in shape and extend alongshore with 


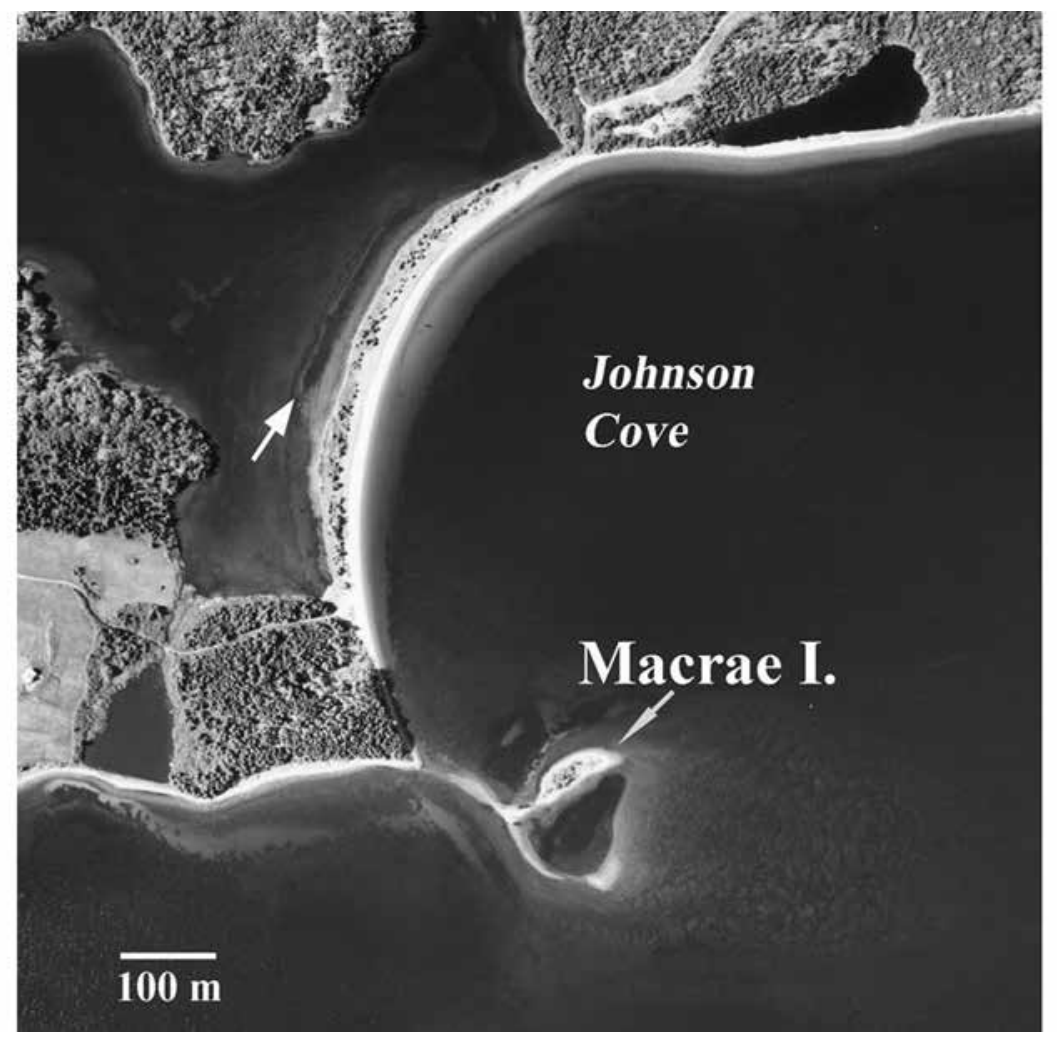

Fig 6 Aerial view of Johnson Cove showing contrasting rates of shoreline change within a small area. Despite similar processes reworking these shores, the coastal barriers at Macrae Island have eroded and deteriorated faster than the larger coastal barrier developed across the head of Johnson Cove. These barriers are made up of multiple beach ridges (marked by trees and arrow). The rapid changes at Macrae Island result from the loss of the outer island which anchored and supplied sediment to the barrier beaches in its lee (air photo 98311-183, June 29, 1998).

multiple ridges near their distal end. Small cuspate nodes can form along drift-aligned barriers if sediment moves alongshore in pulses (Carter et al., 1987; Carter and Orford, 1991). A large coastal barrier complex can include both swash- and drift-aligned components. In the Bras d'Or Lakes, barrier beaches can extend $>1 \mathrm{~km}$ in length. Beach-ridge plains are usually less than $350 \mathrm{~m}$ in length; however in a few cases, multiple beach ridges extend to $700 \mathrm{~m}$, such as along East Bay and Bras d'Or Lake (Fig 2 b locations 4, 44). The larger features exist in areas of longer wave fetch. Two examples, Gillis Beach and Dhu Point, (Fig 2b, locations 45, 3) are used to illustrate how beach ridge morphology can be used to interpret shoreline evolution (Figs 7, 8).

Gillis Beach, Bras d'Or Lake Gillis Beach is located on the north shore of Bras d' Or Lake near Jamesville (Fig 2b, location 45). It extends $700 \mathrm{~m}$ alongshore and encloses 
Gillis Pond (Fig 7a). It is primarily a swash-aligned barrier consisting of multiple beach ridges which are $160 \mathrm{~m}$ wide at its northern end and a smaller, $6 \mathrm{~m}$ wide drift-aligned ridge along its southern part. Water is presently flowing in and out of Gillis Pond across the low southern beach ridge. In 1939 a narrow inlet cut through the barrier south of the multiple ridges. By 1998 the inlet had shifted farther north and despite attempts to keep it open, it has naturally infilled. A survey was completed across the multiple beach ridges (Fig 7b) in the year 2000. Beach ridge elevation increases seaward from $0.02 \mathrm{~m}$ below water level at the most landward ridge to $0.93 \mathrm{~m}$ at the most seaward ridge. The most landward ridges are submerged and covered by wetland vegetation and soft mud varying in thickness from less than 0.1 to $0.5 \mathrm{~m}$. The presence of tree stumps on the submerged ridges (Fig $7 \mathrm{~b}$ ), similar to those reported at a number of other sites by Grant (1994), provides evidence of rising water level. The most seaward beach ridge is higher and composed of wave overwashed sand and granule material which suggests the beach is building as it is pushed landward. If one assumes that the tidal range has not changed and beach ridges were built to similar elevations in the past as they are now, then the landward ridges would have been built when sea level was 0.9 to $1.0 \mathrm{~m}$ lower. Since sea level has risen at an estimated $0.3 \mathrm{~m} /$ century, a minimum age for this complex would be 300 years.

It is not known when the barrier beach closed off Gillis Pond. The morphology of the beach ridges suggests they were initially built by sediment moving mainly from north to south and later became more swash-aligned as sediment accumulated. Today, much of the north shore consists of shore cliffs of gypsum/anhydrite (Fig 3d) and boulder armour along the base of the railway. Therefore, any major sediment supply from the north has been depleted. Bathymetric chart 4279 (Canadian Hydrographic Service, 1991) shows a shoal farther offshore in water depths of 3 to $5 \mathrm{~m}$ extending southward across the front of Gillis Pond. It is postulated that this ridge represents the foundation of a former spit that would have extended at least $1 \mathrm{~m}$ above sea level. It broke apart and the bulk of its sediment shifted onshore to Gillis Beach. On the basis of a sea level rise of $0.3 \mathrm{~m}$ /century, the submerged beach complex would have existed 1000 to 1300 years ago. Field sampling and surveys are needed to confirm this hypothesis.

Dhu Point, East Bay Dhu Point (Fig 2b, location 3) was one of the largest driftaligned shore features in the Lakes. In 1939 it extended $1600 \mathrm{~m}$ alongshore and may have extended even farther to Christmas Island (Fig 8a). Most spits at present including Dhu Point are less than $600 \mathrm{~m}$ in length. In 1939 Dhu Point consisted of three main shore segments, a beach ridge plain at its proximal end (Fig 8a, i) a low narrow, partially submerged central part (ii) and a distal end (iii) which consisted of several recurved ridges. On the basis of beach ridge morphology, it appears the beach ridge plain was supplied sediment from the headland and high shore cliffs just west of Dhu Point (Fig 8a, iv). They are composed of multiple tills and sandy deltaic deposits (Grant, 1994). It is not known when spit growth began. By 1939 the beach ridge plain had been trimmed along its western shore and the central part of the spit had become very low and overwashed by waves which transported increased amounts of sediment into the lagoon. Consequently, there was less sediment available to supply the distal end of the spit and by 1998 most of the spit had become overwashed and drowned, leaving only a few small parts above high tide (Fig 8b). Sediment stored in the beach ridge plain now is being eroded to build a new spit. 

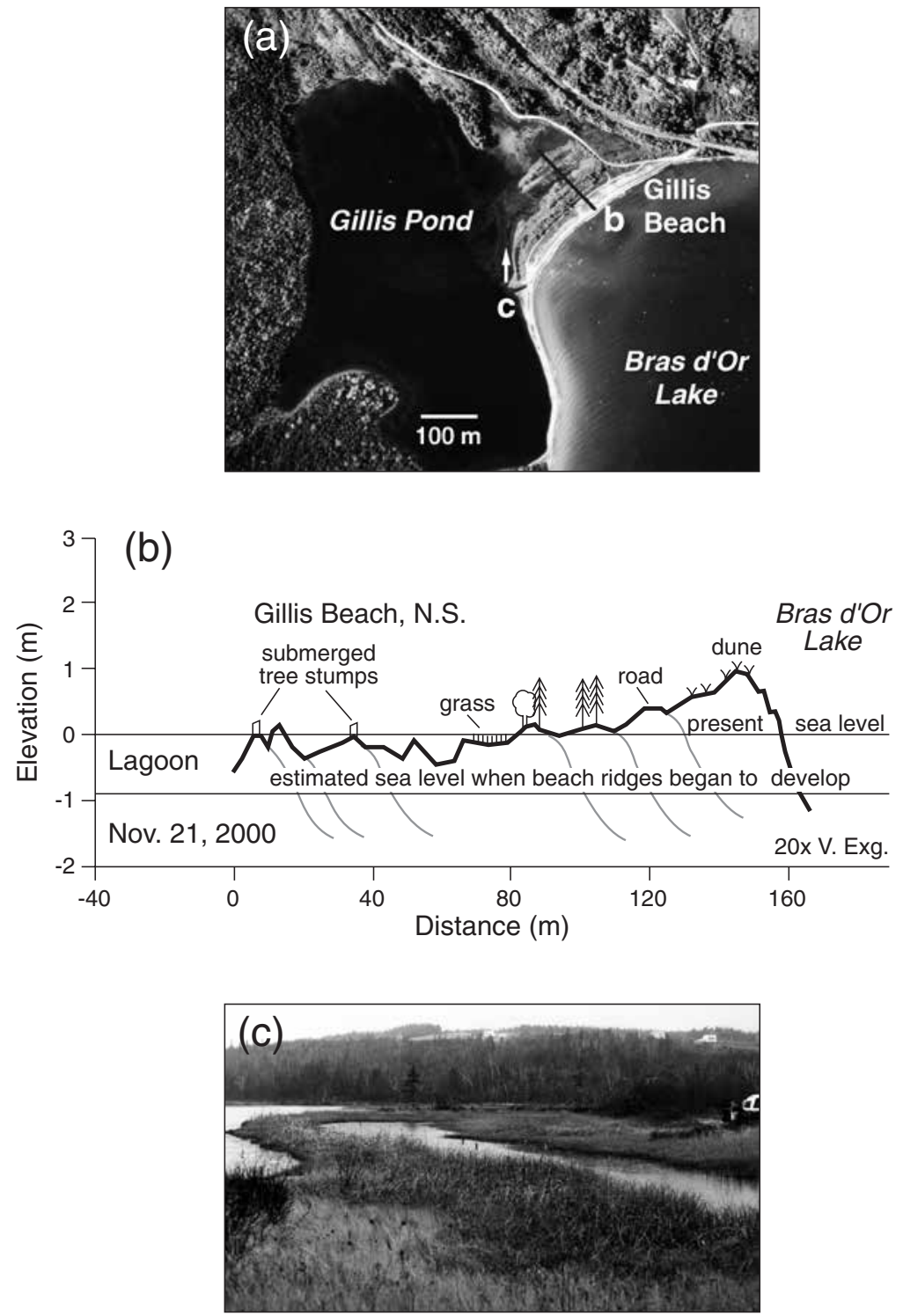

Fig 7 Gillis Beach, Bras d'Or Lake (a) aerial view (air photo 98301-212, June 11, 1998) of multiple beach ridges at north end of Gillis Beach and location of the cross-shore survey shown in (b) which illustrates the seaward rise in elevation of the beach ridge crests. Vertical datum is water level which approximated low tide level. Old tree stumps on the submerged back barrier ridges (c) provide evidence of a rising sea level as does the higher present beach crest which is aggrading by wave overwash. Based on a rate of sea level rise of $0.30 \mathrm{~m} /$ century an estimated minimum age of this beach complex is 300 years. 

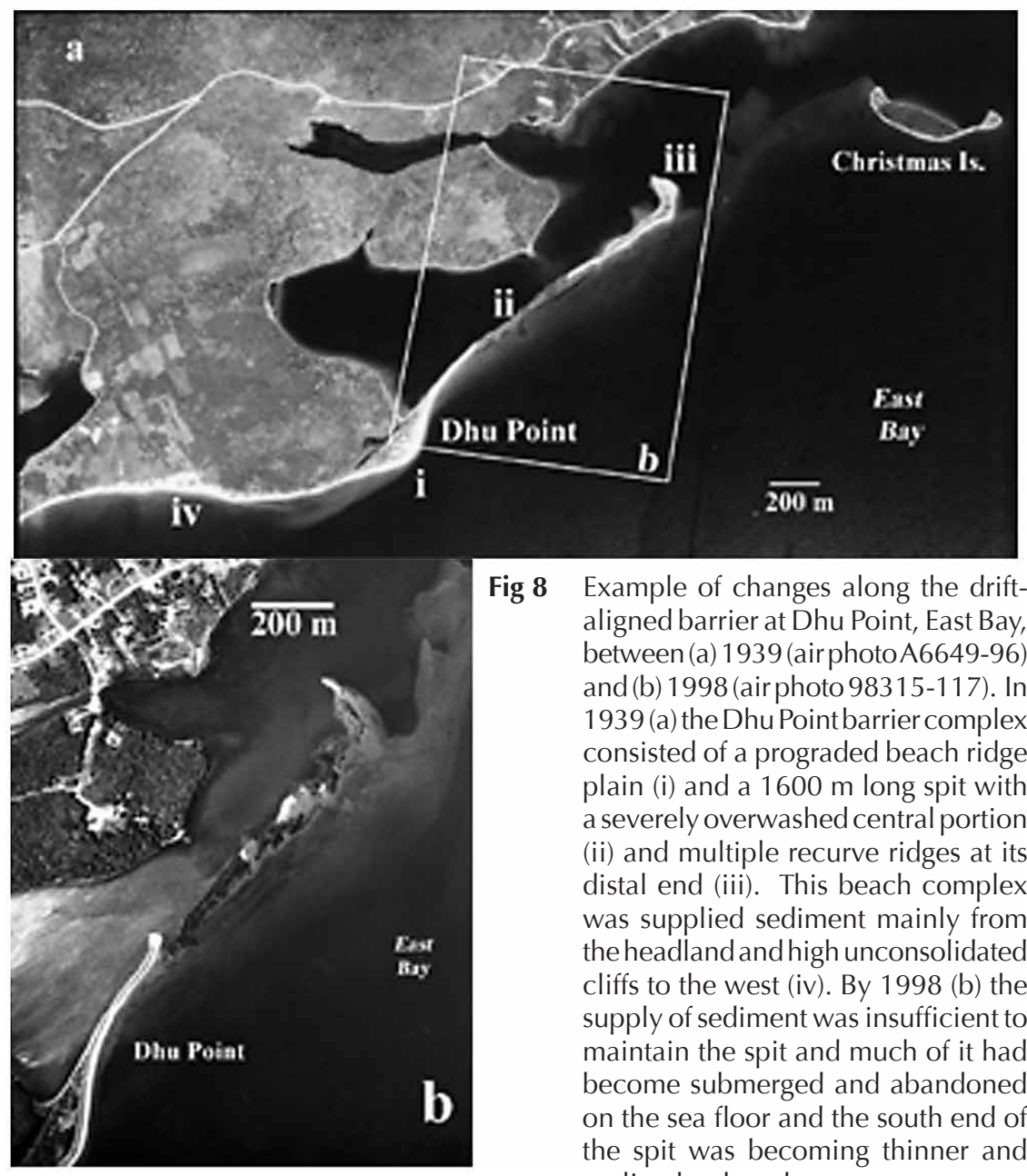

Fig 8 Example of changes along the driftaligned barrier at Dhu Point, East Bay, between (a) 1939 (air photoA6649-96) and (b) 1998 (air photo 98315-117). In 1939 (a) the Dhu Point barrier complex consisted of a prograded beach ridge plain (i) and a $1600 \mathrm{~m}$ long spit with a severely overwashed central portion (ii) and multiple recurve ridges at its distal end (iii). This beach complex was supplied sediment mainly from the headland and high unconsolidated cliffs to the west (iv). By 1998 (b) the supply of sediment was insufficient to maintain the spit and much of it had become submerged and abandoned on the sea floor and the south end of the spit was becoming thinner and curling landward.

\section{Conceptual Model of Coastal Barrier Evolution}

Although very little research has been completed on coastal features within the Bras d'Or Lakes, we can build on previous research of coastal barriers from the nearby Atlantic coast to enhance our understanding of coastal evolution within the Lakes. In a number of recent investigations, researchers observed that coarse-grained barriers experience long intervals of slow change, punctuated by short periods of rapid reorganization (Orford et al., 1991 and Forbes et al., 1990, 1995). They further observed that the response to external forcing factors such as rising sea level, wave energy and varying sediment supply varies locally depending on the intrinsic characteristics of each barrier system such as its present condition, i.e. erosional or 

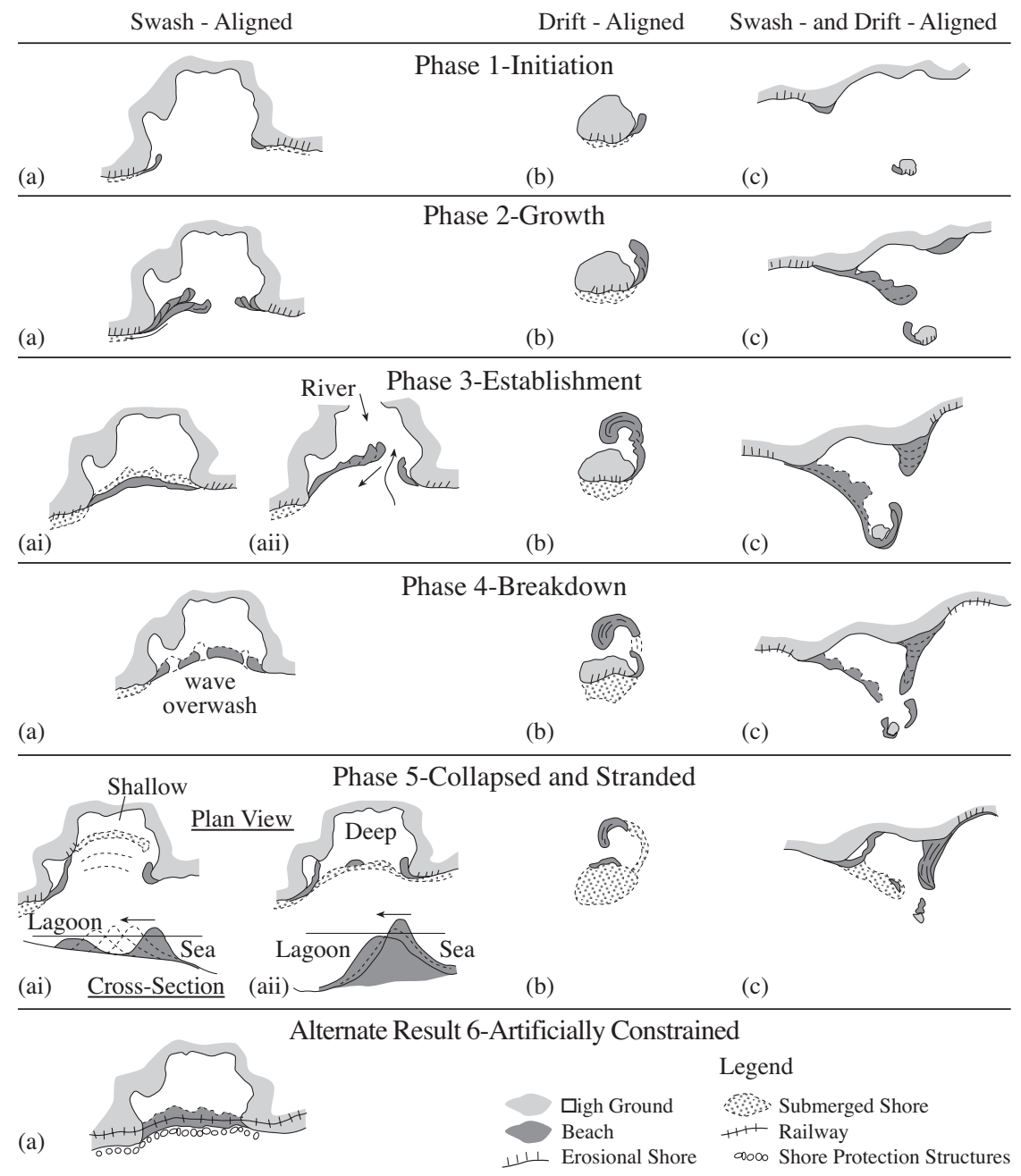

Fig 9 Conceptual model for evolution of (a) swash-aligned, (b) drift-aligned and (c) more complex swash- and drift-aligned coastal barriers in the Bras d'Or Lakes. The model is refined from the models of Orford et al. (1991) and Forbes et al. (1995) for gravel barriers along the outer coast of Nova Scotia. Examples for phases 1 to 5 are shown for the three barrier types and one example of a barrier artificially constrained by human activities - an alternate outcome, 6 is shown. The letters (a to c) are used for linking the text to the diagram. 
depositional, its ability to recycle sediment alongshore or offshore-onshore, and accomodation space for its growth and development. Accomodation space is a function of water depth and distance between headlands or other anchor points. The same authors developed an evolutionary framework for coastal barriers within a transgressive (rising sea level) setting. Within the model, individual barrier structures are initiated, become established and breakdown before the cycle resumes. The model differentiates between drift-and swash-aligned barrier systems but recognises that larger coastal barriers can have components of both and that over time a barrier may switch from a drift- to a swash-aligned system and vice versa.

Table III Phases of Coastal Barrier Evolution in the Bras d'Or Lakes.

\begin{tabular}{ll}
\hline Phase & Defining Criteria \\
\hline $1 \quad$ Initiation & $\begin{array}{l}\text { Short extension offshore of variable shape but most often } \\
\text { pointed, at sharp break in shore orientation, little } \\
\text { or no backbarrier lagoon; may or may not be vegetated. }\end{array}$
\end{tabular}

2 Growth

3

Establishment

Breakdown

$5 \quad$ Collapsed /Stranded
Moderate to long extension offshore; straight, undulating or slightly curved; continuous beach crest with no major cuts by overwash; may consist of multiple shore parallel beach ridges in proximal to central part, or one or more recurve ridges and/or a lower bulge at the distal end; backshore vegetation more mature at proximal end, grasses and bushes more common.

Moderate to long, wide, continuous barrier with smooth, natural curves in planform; usually consists of multiple beach ridges or a wide single beach ridge and backshore dune; both ends joined to other shores or one end joined and wide multiple beach ridges recurved back toward the barrier near distal end; can have a tidal inlet; cross shore gradation in vegetation, e.g. from grass to trees.

Marked differences in longshore physical characterdiscontinuous or segmented barrier. Early stage: broken by wave overwash channels which extend across barrier, or narrow continuous crest with washover lobes extending into backbarrier lagoon; significant variations in barrier width - very narrow segments often the proximal end(s) and distal end may still exhibit growth. Late Stage: one or more barrier segments very low or totally submerged but still intact underwater; small recurve ridges develop at point(s) where barrier becomes submerged; inlets have widened or new ones established; where multiple beach ridges exist, the seaward ridge is highest and aggrading with wave overwash deposits; vegetation patchy and trees dying in low backshore.

Narrow, irregular and segmented, thin strips of exposed beach along landward side of extensive shoal; long segments submerged or parts detached; where lagoon is shallow, parts of original barrier migrate landward and/ or recurve against main shoreline, where lagoon is deep,barrier is totally submerged and intact or central part is submerged and both ends recurve onto main shore forming smaller barrier; initiation 
Table III (cont'd)

of new barrier often observed at proximal end; very patchy or no vegetation.

6 Artificially Constrained

Alternate Forced Outcome

Barrier dominated by straight lines and irregular planform; human-made structures, e.g. buildings, railways, shore protection dominate backshore and/or waterline; tidal inlets constrained or anchored by structures, natural beach ridges or dunes smeared or masked by artificial fill, and manicured backshore vegetation which alters natural water retention and drainage.

Examples from the Bras d'Or Lakes were selected from the earliest (1930s) and the most recent (1998) vertical aerial photographs to illustrate and refine this evolutionary model (Fig 9). A significant benefit of investigating shoreline evolution in the Lakes is that many of the older submerged features are better preserved and more visible on vertical air photos than along the open ocean coast where they are modified by higher energy waves and are less identifiable. Criteria used to identify the phases of barrier evolution in the Lakes are listed in Table III.

Phase 1-Initiation Barriers may be initiated by waves transporting sediment from

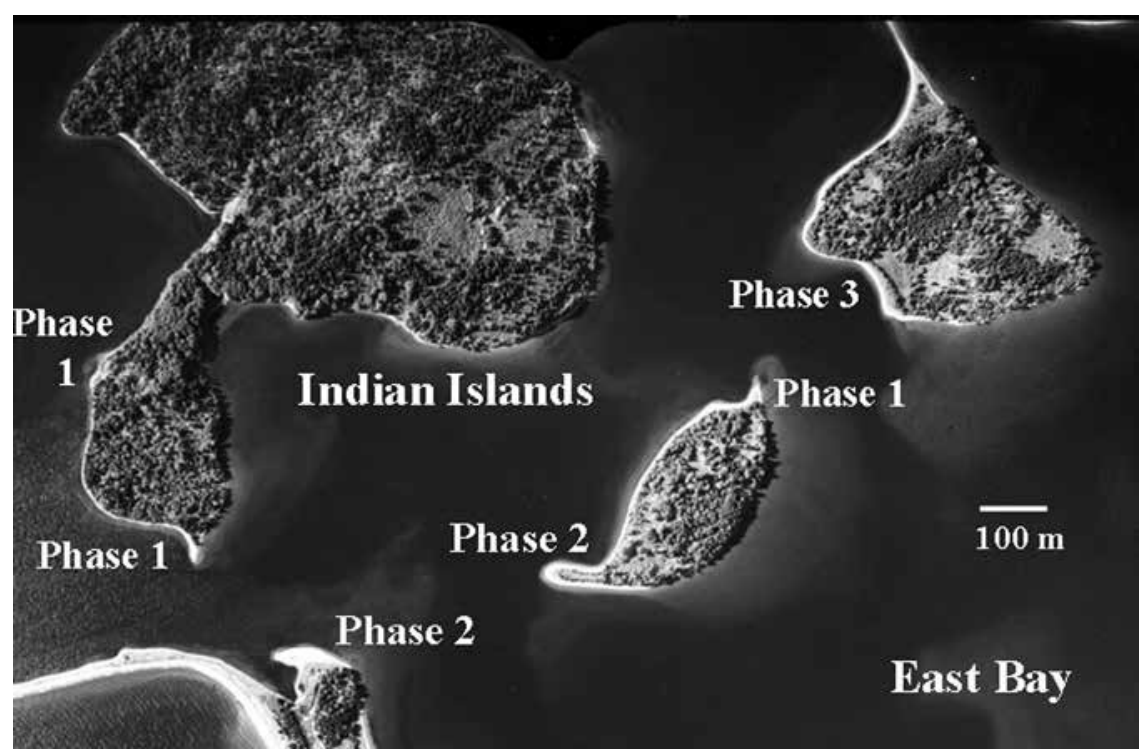

Fig 10 Aerial view (photo 98301-237) of the Indian Islands, East Bay where several shore features are being initiated (phase 1). Drift-aligned shore features are initiated at sharp changes in shoreline orientation, they are small and pointed or cusp shaped. If sediment supply continues the features become extended (phase 2) as shown by two examples in this photograph. The barrier marked as phase 3 is smaller in extent than most listed in Appendix but it has multiple beach ridges, a stable smooth outline and consists of a cross-shore gradation in vegetation. 
point or line sediment sources, most often shore cliffs and develop at sites of significant change in shoreline configuration (Fig. 9, phase 1a). Initially, sediment is transported alongshore forming spits or forelands (Fig 10) but with further growth these features can become swash-aligned barriers depending on shoreline geometry and local bathymetry.

Phase 2-Growth The growth of a barrier depends on sediment supply and water depths. For example, where the adjacent waters are shallow, sediment can quickly accumulate and extend farther away from the source (Fig. 9, phase 2a, c); whereas if deeper water exists, the accumulation feature will generally be forced to extend close to shore, toward the lee of the source (Fig 9, phase 2b; Fig 10,11). A barrier may extend in width as multiple beach ridges (Fig 9, phase 2a), and /or in length as a series of recurve ridges or both (Fig 9, phase 2 b).

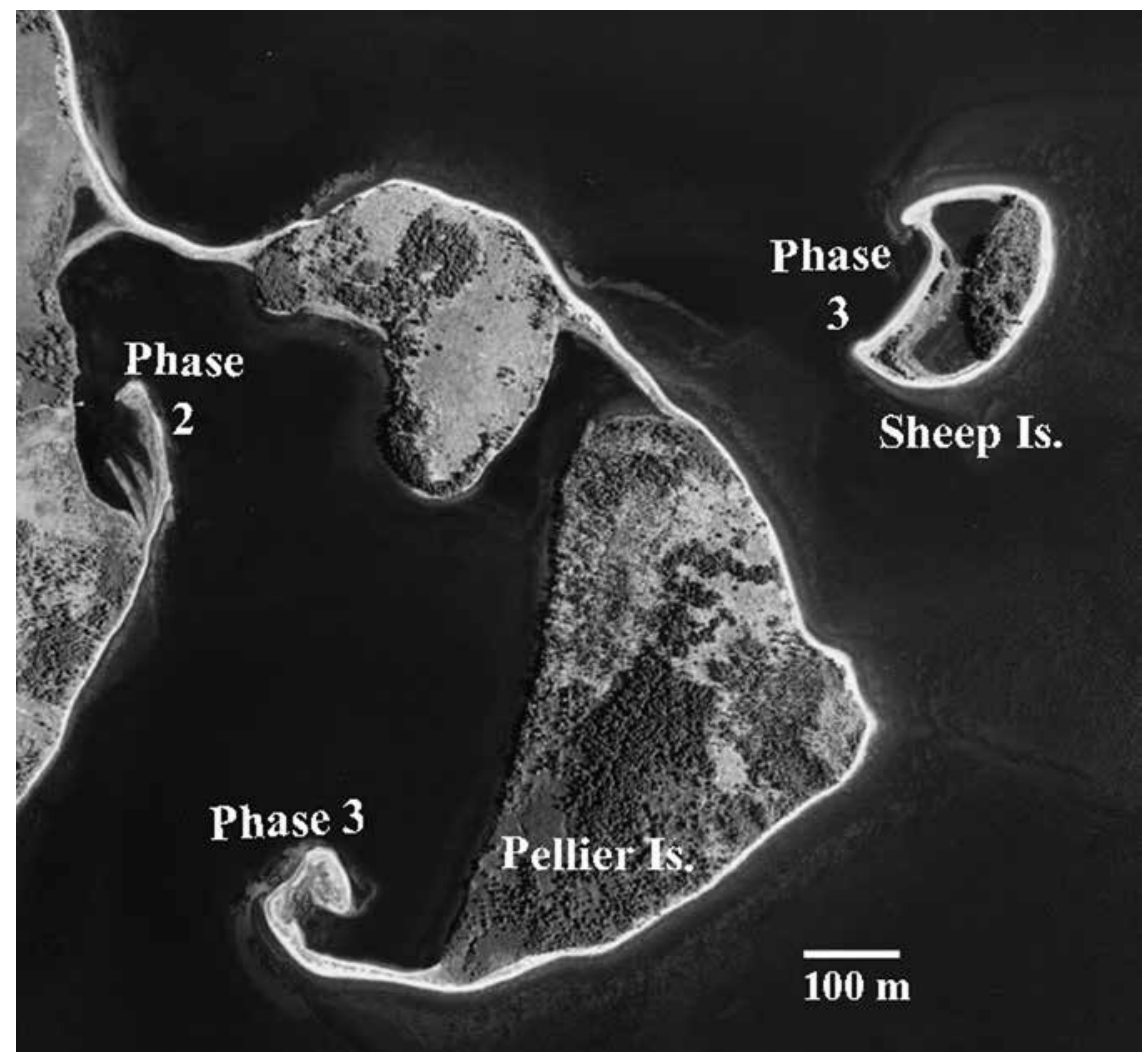

Fig 11 Aerial view (photo 98320-49) of Pellier and Sheep Islands at the entrance to Malagawatch Harbour. The spit to the left with multiple ridges appears to be still growing and is in phase 2 despite some erosion of its proximal end. The two features labelled as phase 3 have become more established. Growth of the spit on Pellier Island has been arrested and it has hooked back upon itself and attained phase 3 . Two spits have joined to form a double loop structure in the lee of Sheep Island where a wider beach with multiple ridges and connection at both ends provides more stability; therefore, it is considered in phase 3. 
Phase 3-Establishment If sediment supply is sufficient, the spit can attach to an adjacent shore, outcrop, or island and become a better stabilized barrier beach or tombolo (Fig 9, phase 3, Figs 10,11,12, Appendix). Established barriers are often covered by a well defined gradation in cross- shore vegetation varying from dune grass to trees. The seaward crest or duneline is continuous and fairly similar alongshore. Once a barrier is established, if sediment continues to be supplied, beach growth may continue over several centuries or millenia. Where sea level is rising, the seaward ridges will be built higher than the older landward ones which were built at a time of lower sea level (Fig 5,7b). In a drift-aligned setting, continued sediment supply can result in sediment spill over into the next shoreline compartment and the growth of a new barrier, e.g. Dhu Point, East Bay (Fig 8a,9, phase 3c). Another situation commonly observed in the Bras d'Or Lakes is where a spit extends behind its anchor and point source to form a loop structure, e.g. Sheep Island, Malagawatch Harbour (Fig 11). In some instances paired loop structures may develop, and in other cases, two flanking spits may join to form a single spit or tombolo behind the island (Macrae Island, Fig 6). Water depth, the size of the island and wave dynamics control the growth pattern. Established barriers may exhibit erosional features after storms but generally have the capability to recover and rebuild.

Phase 4-Breakdown As sediment supply diminishes, either because of depletion of the source through natural erosion, or the interference of sediment supply by human-made structures, the barrier beach or spit narrows at one or more locations alongshore, and its crest exhibits greater irregularity in elevation and increased discontinuity. In some instances, sediment from the degrading part of a spit is transported alongshore to maintain growth of the distal end. Wave overwash channels are cut farther across the barrier crest or dune (Fig 9, phase 4a, Appendix). In the later stages of this phase, waves commonly transport sediment landward to build the lagoon shore. Short segments of barrier may become lowered and submerged at high tide (Fig 9, phase 4b,c).

Phase 5-Collapse or Stranding A further reduction in sediment supply and depletion of a barrier generally results in its landward migration (Fig 9, phase 5, Fig 13, Appendix). If the sea level is rising two situations may occur in the Lakes: (A) If the lagoon is shallow, wave overwash may transfer beach sediment landward and infill the lagoon allowing swash aligned barriers to migrate farther landward through a series of beach rollover cycles of alternate wave overwash and crest rebuilding (Fig 9, phase 5 ai). Continued landward migration of a barrier results in longshore stretching and given a sequence of storms can result in its submergence and stranding before it can reach the far shore (Carter et al., 1987; Taylor et al., 1999); and (B) If the lagoon is deep, a coastal barrier can become flattened, submerged and stranded along its original backshore (Fig 9, phase 5aii). A good example is Barachois spit, located in the channel east of Long Island, St. Andrew's Channel, where the distal end of the spit photographed by Tarr (1898) is now a shoal detached from its proximal end at high tide. By 2000 a new recurve ridge had developed closer to the main shore but water depth was too great to allow appreciable growth. The model for drift-aligned barriers comes from examining Sheep and Macrae Islands at the mouth of Malagawatch Harbour (Figs 6,11). The loop structures breakdown (Fig 9, phase 4b) as the island anchor and sediment source become depleted and finally become stranded following erosion of the island (Fig 9, Phase 5b). It was observed at Macrae Island and McPhee Island (Figs $6,10)$, that some sediment is transferred inshore from the stranded barriers to initiate the development of new spits. This recycling of sediment allows the transformation of shores from one phase to another. 

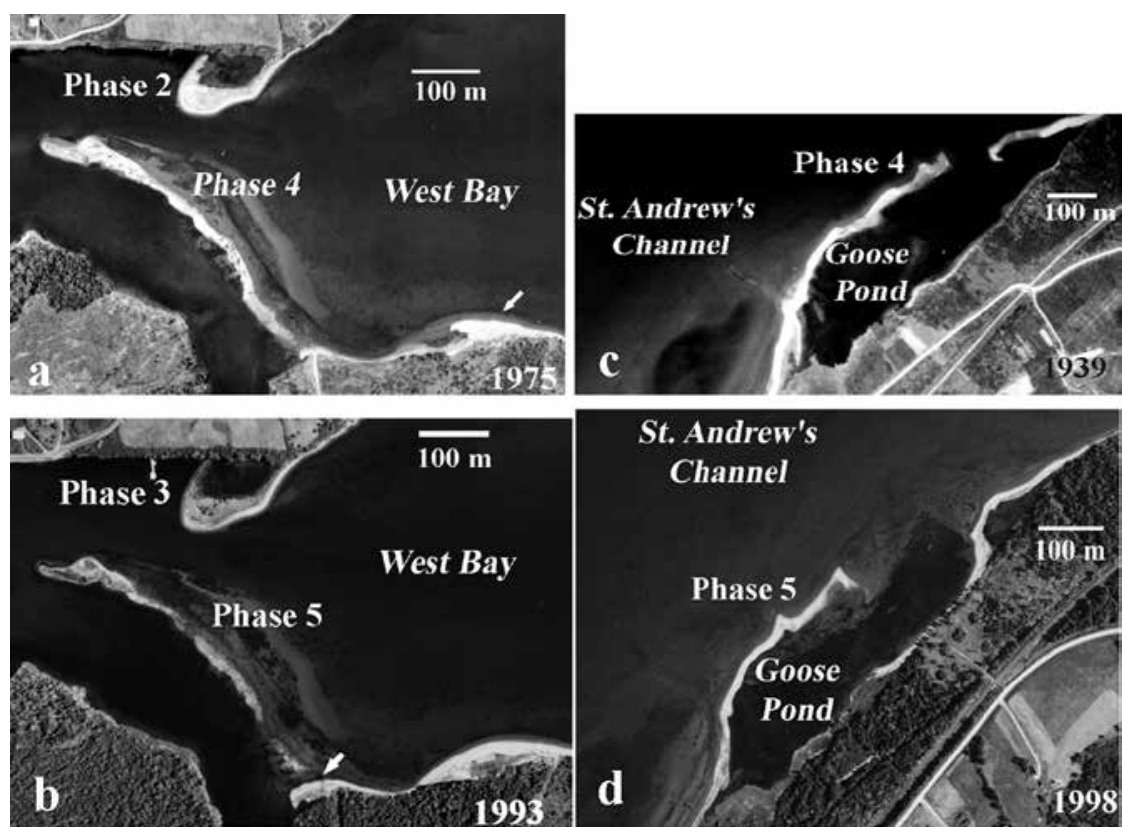

Fig 12 Two examples of barriers breaking apart, becoming submerged and migrating shoreward. At West Settlement, West Bay the entire length of the spit was lowered, overwashed by waves, and segmented between (a) 1975 (photo 75204-101) when the sediment source was depleted (arrow) and (b) 1993 (photo 93303-29) when longshore sediment transport was resumed from the east and a new spit developed across the foundation of the older one (arrow). At Goose Pond, St. Andrew's Channel, between (c) 1939 (photo A6651-60) and (d) 1998 (photo 98321-182), the northern portion of the barrier formed a separate smaller barrier against the main shoreline and the southern portion of the original barrier became shorter, more narrow and a new recurve ridge developed as part of the natural breakdown phase.

There are several examples including Goose Pond, St. Andrew's Channel, where the proximal ends of barriers have migrated landward to form new cuspate barriers (Fig 2b, location 73; Fig 9, phase 5c;) even though the central part of the barrier has been submerged and stranded. These new barriers, because they are smaller and have reconnected to the main shore, are more stable and considered to have evolved into phase 3 (Fig 12d). Once barriers have become stranded new spit growth often is observed at the proximal end of the old barriers such as West Bay Settlement, West Bay (Fig 2b, location 29, Fig 12b), signifying the resumption of sediment supply and re-initiation of phase 1.

Phase 6 -Artificially Constrained An alternative outcome of barrier change results when barriers no longer exhibit their natural character because they have been altered or constrained by human activities (Fig 13). In the past many barriers particularly along the south shore of St. Andrew's Channel became the foundation for railways and roads. 

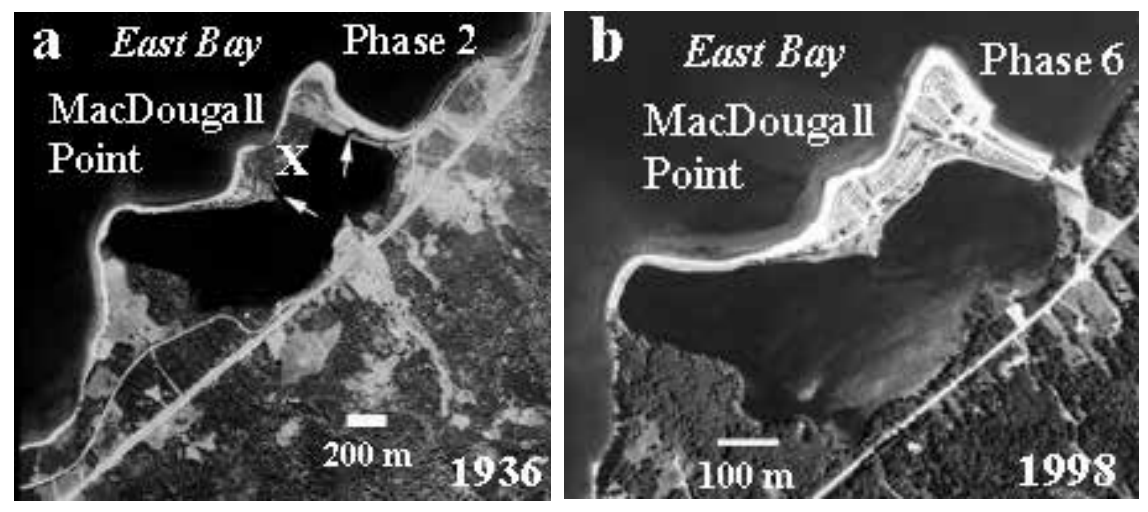

Fig 13 Two views of MacDougall Point, East Bay (a) in its natural state in 1936 when barriers had linked the central island $(X)$ to the main shoreline forming a tombolo (air photo A5450-91) and in (b) 1998 (air photo 98322-3) when the coastal barrier was constrained in its natural evolution by groynes and other shore structures. It now forms the Ben Eoin campground and trailer park, a popular summer retreat. By 1998 only one of two natural outlets observed in 1936 (arrows) has been maintained.

Fill was required to build the railway bed across low coastal areas and boulders and quarry rock were added to protect the artificial shore structures from wave erosion (Fig 9, phase 6 a). The apparent stability of phase 2 and 3 barriers makes them attractive sites for this type of construction and subsequent alteration to phase 6 . When natural shoreline erosion is halted it reduces the volume of sediment supplied to adjacent shores and can, in some cases, accelerate their erosion.

Residential developments or recreational activities on large barriers can result in compaction and modification of the natural surface, lowering of crest elevations and change or loss of natural vegetation cover. MacDougall Point, the site of Ben Eoin campground, is an example of a barrier in phase 6 (Fig 2b, locations 11,13). The development of the campground has required significant maintenance to protect the investment, including stabilizing the inlet, modifying the natural beach ridges and the building of many small groynes (a narrow structure constructed of timber, rock or concrete roughly perpendicular to shore with the intent to trap sediment transported alongshore and maintain or increase beach width).

Human activities are expanding along the Bras d'Or Lakes. In East Bay alone, 63 groynes, 44 seawalls and 19 rip rap structures were observed along the shores during the 1996 aerial video survey (Taylor and Frobel, 1998). There are also increased demands by local residents to reopen or modify the tidal inlets through small barriers to improve lagoon circulation and reduce odor; to allow the passage of fish or pleasure craft; and to reduce flooding inland (McSween, 2000). Artificial structures decrease the ability of natural shores to re-organise and recycle their sediment to form new beaches as sea level rises. Human actions introduce new phases of stability at irregular intervals which tends to disrupt and/or accelerate natural processes. The impacts of such actions have received little attention and are poorly documented. It is known that coastal barriers will breakdown naturally. How much human activities will accelerate the processes is unknown. 


\section{Present Status of Coastal Barriers on the Bras d'Or Lakes}

Criteria were developed for identifying specific phases of coastal barrier evolution (Table III) and applied to 80 coastal barriers of $250 \mathrm{~m}$ in length within the Bras d'Or Lakes. Their physical characteristics and phase of development were assessed using the 1996 aerial video and they are listed in the Appendix. Further ground investigations should be completed to confirm the details but these results provide a useful guide concerning the present status of the coastal barriers. Although they exist, no barriers in phase 1 and only a few in phase 2 are listed in the appendix because of the restriction in the size of barriers examined. Overall $39 \%$ were in the building or established phases 2 and 3; 43.9\% were in breakdown and collapse phases 4 and 5; $13.4 \%$ were in transition between phase 3 and 4 , and $3.7 \%$ were significantly constrained by human activities. Barriers identified in transition between phase 3 and 4 exhibited minor erosional and breakdown characteristics which may only be temporary and the result of recent storms. Many of these barriers may recover and remain in phase 3 depending on their ability to recycle and reorganise sediment. Coastal barriers in phase 4 and 5 are most sensitive to human activities. Care should be taken when approving land use and building permits, on and adjacent to these coastal barriers to avoid accelerating the natural breakdown process and loss of human-built coastal infrastructure.

\section{Future Research and Summary}

A conceptual model of barrier beach evolution was developed for the Bras d'Or lakes. Five phases of natural evolution were defined: (1) initiation, (2) growth, (3) establishment, (4) breakdown and (5) collapse or stranding. The resumption of the cycle and initiation of a new, often much smaller barrier can occur following phase 4 or 5 . An alternative outcome (6) occurs when a natural barrier becomes constrained and/ or modified by humans to the extent that natural processes are altered significantly, and it is unable to evolve naturally. The model serves as a guide for an initial evaluation of the stability of barriers and provides information to users so that the negative impacts of human activities can be reduced. Nearly $44 \%$ of the large coastal barriers listed were identified in the breakdown phase which means they are more sensitive to human interference. Hence, a greater awareness of the natural evolutionary process is required if we are to avoid accelerating natural breakdown of shores and minimize the loss of coastal infrastructure.

The magnitude of processes such as the impacts of sea ice on coastal stability and sediment transport by waves both warrant further investigation to better understand rates of coastal change relative to the more wave exposed Atlantic coast. Much of the information presented in this paper is based on visual observations with only a few quantitative measurements. Air photos have provided information about historical changes on land but only detailed mapping of the sea floor, using new technology such as multibeam bathymetric surveys, can provide similar information offshore. Recent multibeam surveys completed by the Canadian Hydrographic Service (Paul, 2000) suggest a number of potential drowned shores which could be surveyed and sampled to document coastal evolution during the past few thousand years. From the 1996 aerial video survey a number of barriers were identified as having already gone through several phases of evolution. They would be primary sites for further surveying and sampling of older beach ridges and coring of lagoon bottom sediment to obtain 
material for dating the age of the barriers and analyzing when and if the lagoons switched from freshwater to saline conditions. Information about the age of the coastal barriers would provide a better understanding of the duration of specific cycles of barrier evolution and contribute to a better history of sea level change in the Lakes and a reconstruction of the paleoshorelines (Shaw et al., 2002).

\section{Acknowledgments}

The research was supported by the Geological Survey of Canada, Atlantic (GSCA) and is GSCA contribution 2001 003. The authors wish to acknowledge Dave Frobel (GSCA) for assistance with the field surveys in 2000 and Andy Sherin and Jennifer Harding (GSCA) for providing digital base maps and shoreline lengths. We thank the librarians at the Nova Scotia Department of Natural Resources Library for access to their collection of air photographs. Suggestions for improvements to earlier versions of the manuscript by Dr. Philip Giles, Saint Mary's University and Dave Frobel of GSCA are appreciated. Comments by Dr. Robin Davidson-Arnott, Guelph University and an anonymous reviewer were also most useful. Thanks are also extended to Ken Hale, (GSCA) Electronic Publishing, for the illustrations.

\section{References}

American Geological Institute 1980. Glossary of Geology, Second edition (eds R.L. Bates and J.A.Jackson), 751 p.

Boyd, R., Bowen, A.J. and Hall, R.K. 1987. An evolutionary model for transgressive sedimentation on the Eastern Shore of Nova Scotia. IN Glaciated Coasts (ed. D.M. Fitzgerald and P.S. Rosen), Academic Press, San Diego, pp. 87-114.

Canada, 1972. Facts from Canadian Maps, A Geographical Handbook. Surveys and Mapping Branch, Department of Energy, Mines and Resources, Ottawa, Canada, 62p.

Canadian Hydrographic Service 1991. Bras d'Or Lake, Chart 4279, 1:60,000 scale, Fisheries and Oceans Canada.

Canadian Hydrographic Service (CHS) 2000. Canadian Tide and Current Tables 2000, Volume1 Atlantic Coast and Bay of Fundy, Fisheries and Oceans Canada, 96 p.

Carrera, G., Vanicek, P. and Craymer, M.R. 1990. The compilation of a map of recent vertical crustal movements in Canada. Report to Geodetic Survey of Canada, DSS Research Contract 50SS.23244-7- 4257.

Carter, R.W.G., and Orford, J.D. 1991. The sedimentary organisation and behaviour of drift-aligned gravel barriers. Coastal Sediments '91: Proceedings of a Specialty Conference on Quantitative Approaches to Coastal Processes: Seattle, Washington, June 25-27, 1991, (ed. N.C. Kraus, K.J. Gingerich, and D.L. Kriebel), American Society of Civil Engineers, 1: 934-948.

Carter, R.W.G, Orford, J.D., Forbes, D.L. and Taylor, R.B. 1987. Gravel barriers, Headlands and Lagoons: an evolutionary Model; Coastal Sediments '87: Proceedings of a Specialty Conference on Advances in Understanding of Coastal Sediment Processes: New Orleans, Louisiana, May 12-14, 1987, (ed. N.C. Kraus), American Society of Civil Engineers, II: 1776-1792.

Carter, R.W.G., Orford J.D., Forbes, D.L. and Taylor, R.B. 1990. Morphosedimentary development of drumlin-flank barriers with rapidly rising sea level, Story Head, Nova Scotia; Sedimentary Geology, 69: 117-138. 
Cruising Nova Scotia 1997. The Cruisers' Guide to Nova Scotia's Coastline, including the beautiful Bras d'Or Lakes, Cape Breton Island. Diversity Special Interest Publishing Co. Ltd. In cooperation with the Nova Scotia Economic Development and Tourism Marketing, Halifax, 208 p.

Fennell, J. 2001. (Department of Fisheries and Oceans, Dartmouth, N.S) Personal Comunication.

Forbes, D.L. and Taylor, R.B. 1987. Coarse-grained beach sedimentation under paraglacial conditions, Canadian Atlantic coast. IN Glaciated Coasts (ed. D.M. Fitzgerald and P.S. Rosen), Academic Press, San Diego, pp. 51-86.

Forbes, D.L., Taylor, R.B., Shaw, J., Carter, R.W.G. and Orford, J.D. 1990. Development and stability of barrier beaches on the Atlantic coast of Nova Scotia. IN Proceedings, Canadian Coastal Conference (Kingston), National Research Council, Ottawa, pp. 83-98.

Forbes, D.L., Orford, J.D., Carter, R.W.G., Shaw, J. and Jennings, S.C. 1995. Morphodynamic evolution, self-organisation and instability of coarse-clastic barriers on paraglacial coasts; Marine Geology, 126: 63-85.

Goldthwait, J.W. 1924. Physiography of Nova Scotia; Geological Survey of Canada, Memoir 140, 179 p.

Grant, D.R. 1988. Surficial Geology, Cape Breton Island, Nova Scotia; Geological Survey of Canada Map 1631A, 1:125,000 scale.

Grant, D.R. 1994. Quaternary Geology, Cape Breton Island, Nova Scotia; Geological Survey of Canada Bulletin 482, Natural Resources Canada, Ottawa, 159 p.

Johnson, D.W. 1925. The New England Acadian Shoreline, (1967 facsimile of the 1925 edition) Hafner Publishing Company, New York and London, 608 p.

Lynch, D.W. 1995. Late Quaternary acoustic stratigraphy and glacial history of the Bras d'Or Lakes using seismic data and cores; B.Sc. Honours Thesis, Geology Department, Saint Mary's University, Halifax, Nova Scotia, 63 p. plus 2 maps.

McSween, B. 2000. (N. S. Dept. Natural Resources, Halifax. N. S.) Personal communication.

Miller K.R. and Livingstone, D.A. 1993. Late-Holocene changes in sea level and environment on eastern Cape Breton Island, Nova Scotia, Canada; The Holocene, 3: 211-219.

Orford, J.D., Carter, R.W.G. and Jennings, S.C. 1991. Coarse clastic barrier environments: evolution and implications for Quaternary sea-level interpretation; Quaternary International, 9: 87-104.

Parkes, G. and Gray, J.M. 1992. Scotia / Fundy marine weather guide; Environment Canada Atlantic Region, Catalogue No. En 56-90/1992 E, 100 p.

Paul, K. 2000. (Canadian Hydrographic Service, Dartmouth, N. S.) Personal communication.

Petrie, B. 1999. Sea level variability in the Bras d'Or Lakes. Atmos.-Ocean 37; 221-239.

Petrie, B. and Bugden, G. 2002. The Physical Oceanography of the Bras d'Or Lakes; Proc. N.S. Inst. Sci., 42, 11-38.

Shaw, J., Taylor, R.B. and Forbes, D.L. 1993. Impact of the Holocene Transgression on the Atlantic Coastline of Nova Scotia; Géographie physique et Quaternaire, 47: 221-238.

Shaw, J., Piper D.J.W. and Taylor R.B. 2002. Marine Geology of the Bras d'Or Lakes, Nova Scotia. Proceedings Nova Scotia Institute of Science, 42: 127-147.

Sherin, A. 1998. (Geological Survey of Canada (Atlantic), Dartmouth, N. S.) Personal communication. 
Smith, M.W. and Rushton, D.K. 1964. A study of barachois ponds in the Bras d'Or Lake area of Cape Breton, Nova Scotia. Proc. N.S. Inst. Sci., 26: 3-17.

Stea, R.R., Conley, H. and Brown,Y. 1992. Surficial Geology of the province of Nova Scotia; Nova Scotia Department of Natural Resources, Map 92-3, Scale 1:500,000.

Tarr, R.S. 1898. Wave-formed cuspate forelands, The American Geologist, XXII,, No.1: 1-12.

Taylor, R.B. and Frobel, D. 1998. Aerial video surveys: The Bras d'Or Lakes Shoreline, Nova Scotia. Geological Survey of Canada Open File Report 3656, 58 p.

Taylor, R.B., Forbes, D. L., Frobel, D. and Shaw, J. 1999. Barrier Crest Surveys and Their Value for Documenting Longshore Variability in Gravel Beach Dynamics; Proceedings of the 1999 Canadian Coastal Conference, Victoria, B.C., May 19-22, 1999, pp. 669-685.

Woodman, J.E. 1899. Shore development in the Bras d'Or Lakes; The American Geologist, XXIV: 329-342.

(Received 1 March 2002) 


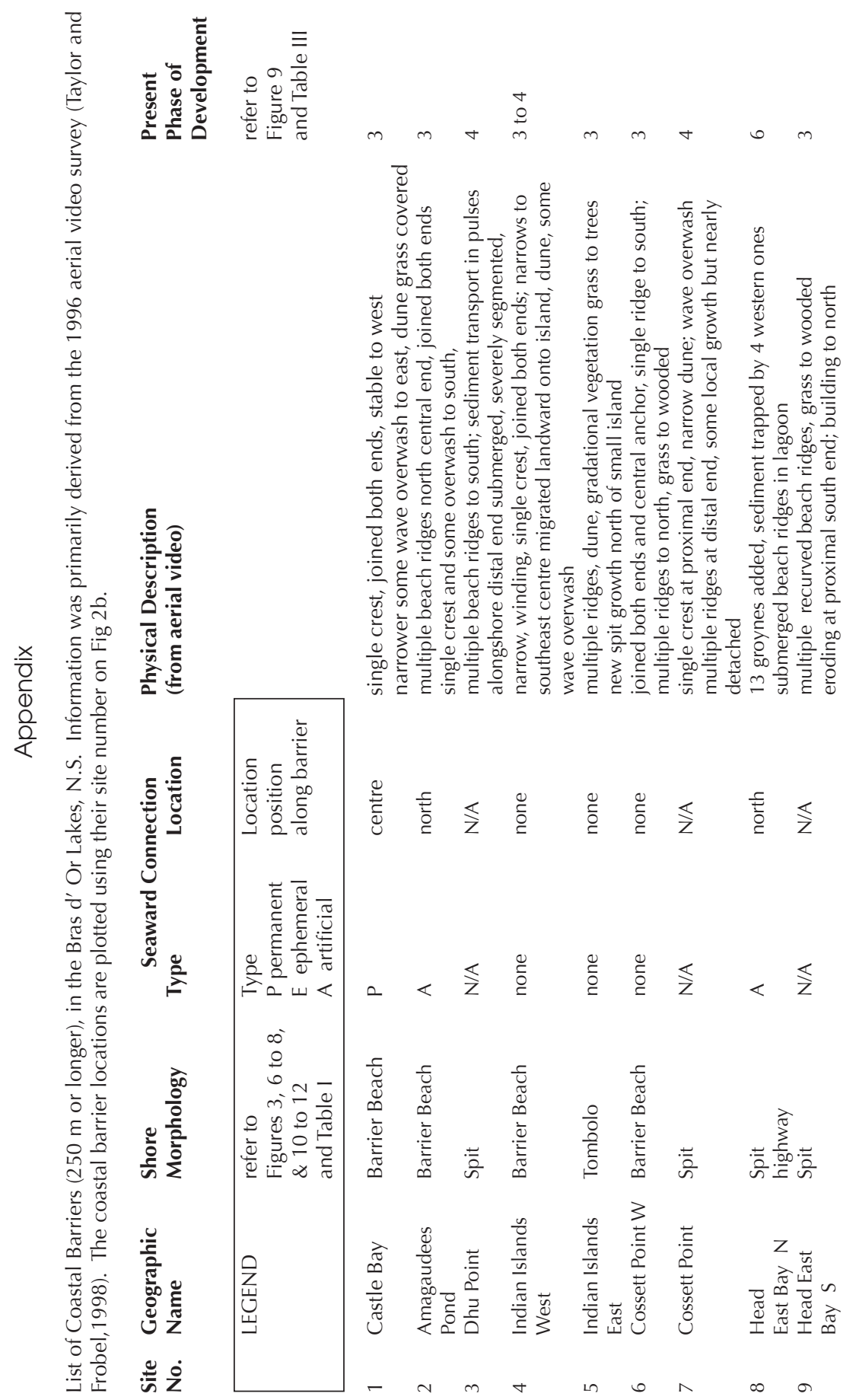




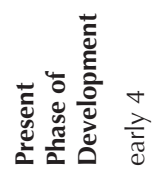

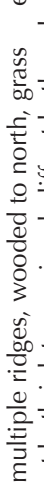

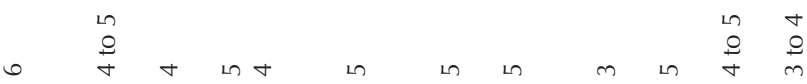

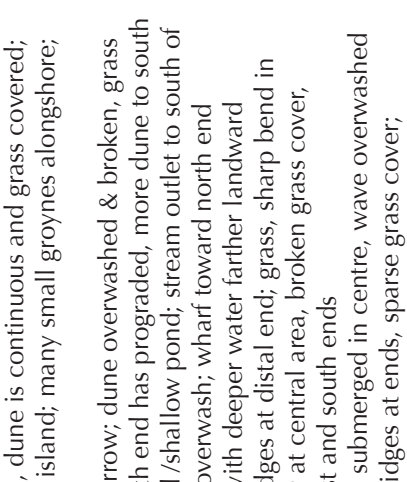

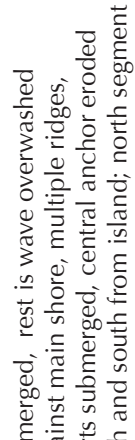

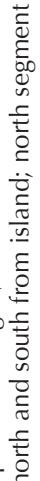

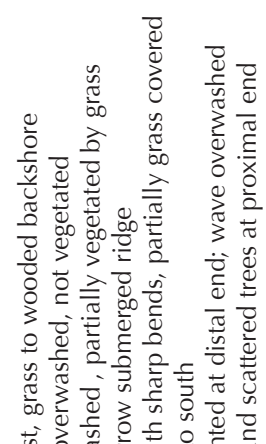

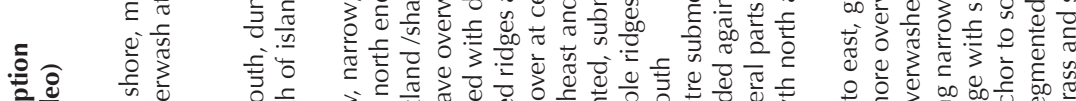

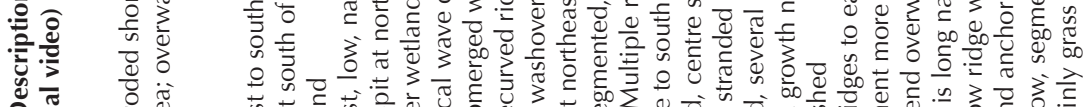

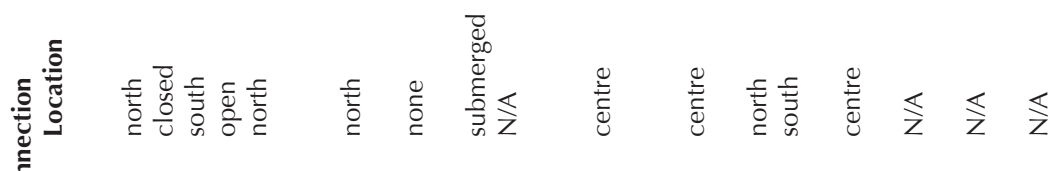

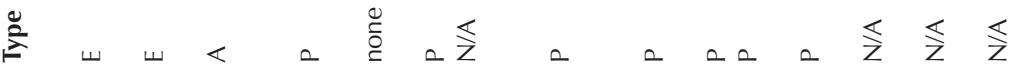

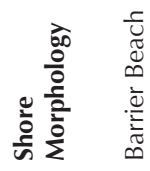

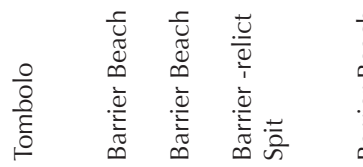

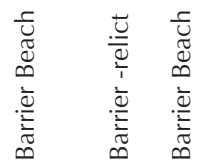

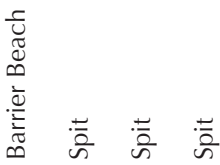

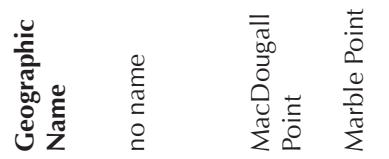

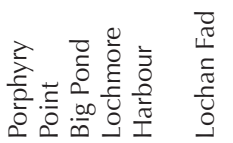



菅

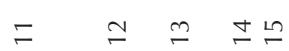

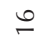

ㅇํ ำ 

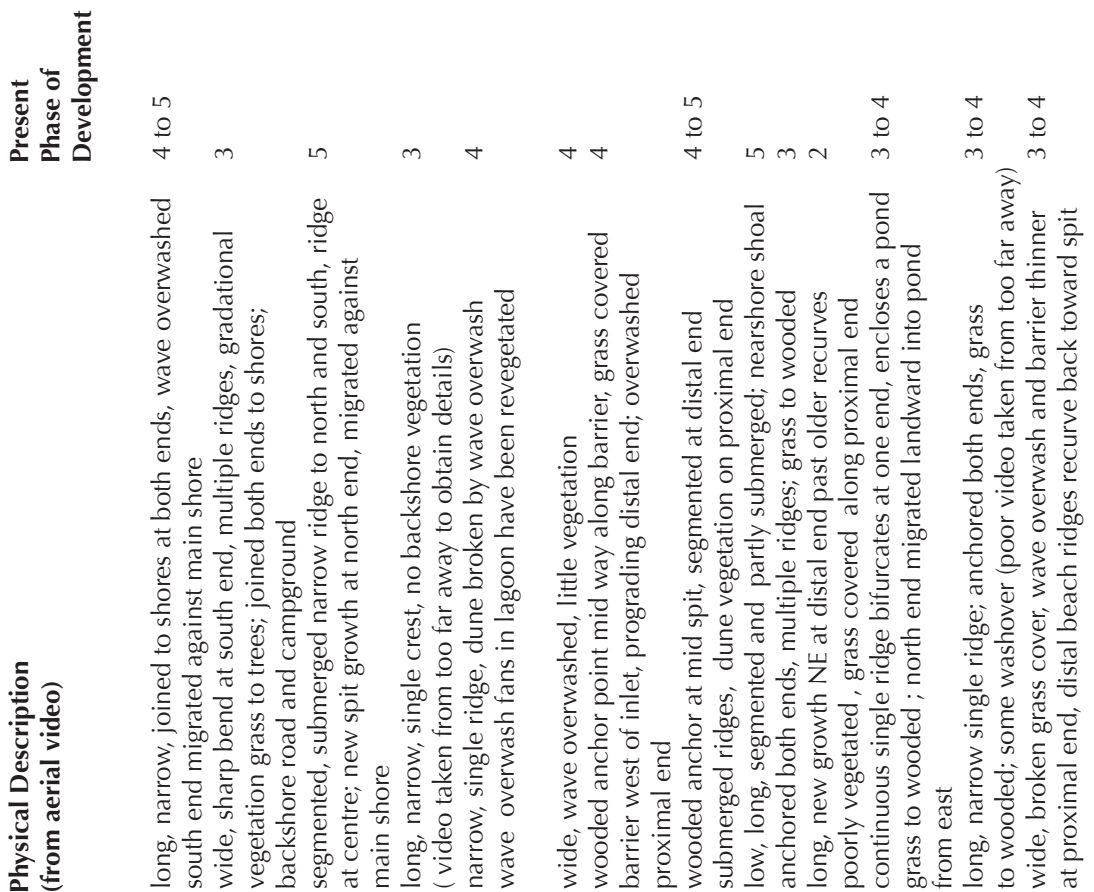

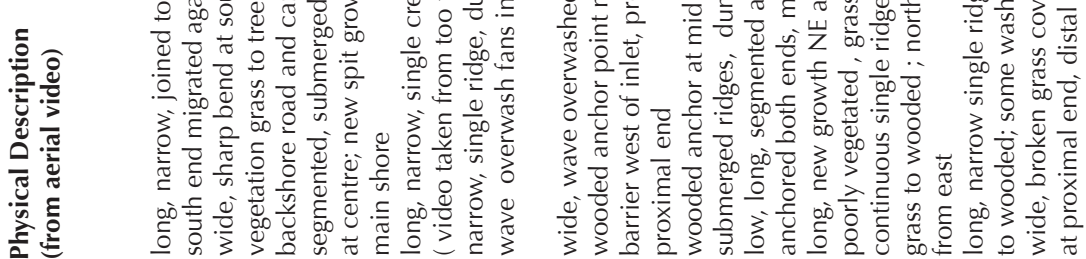

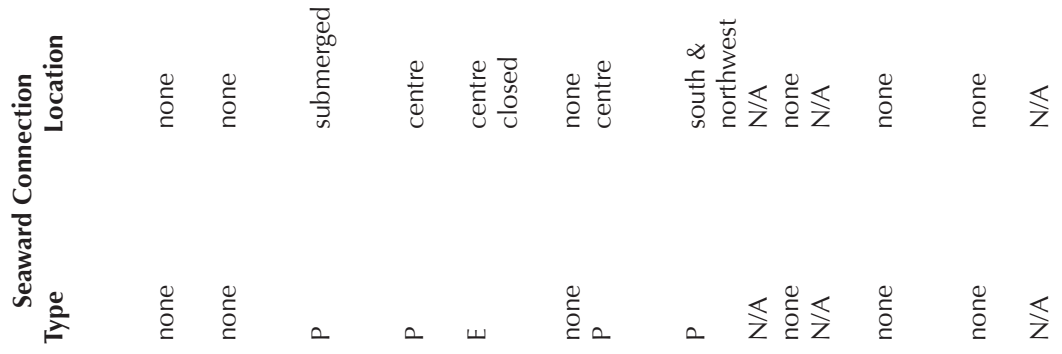

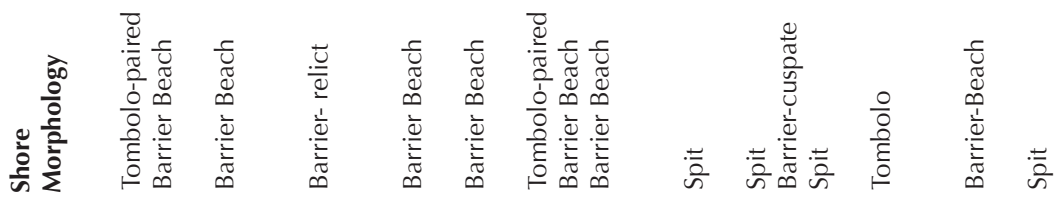

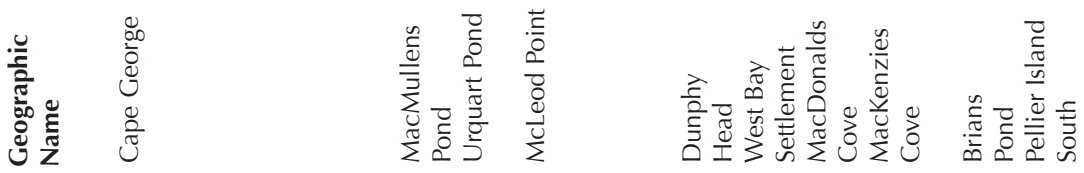

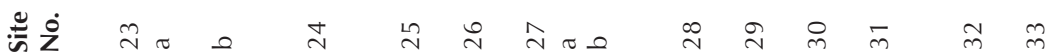




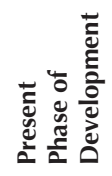

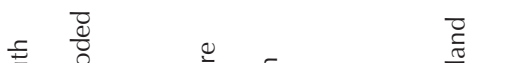

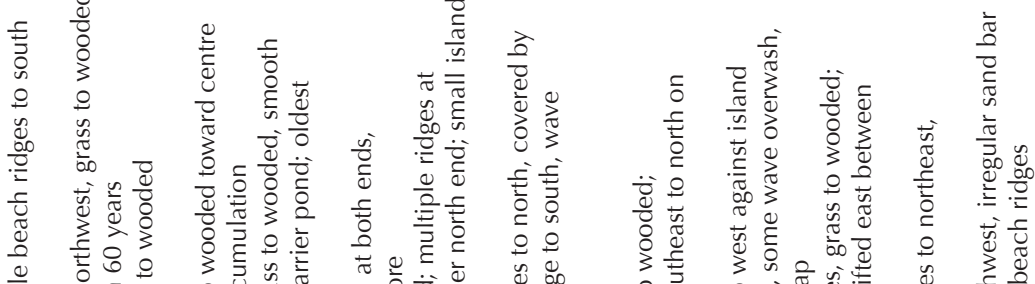

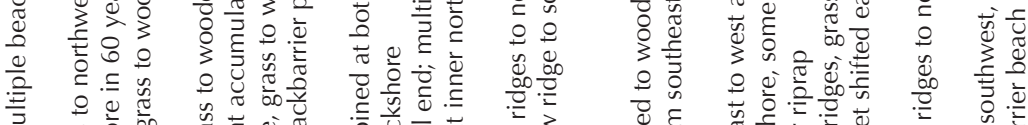

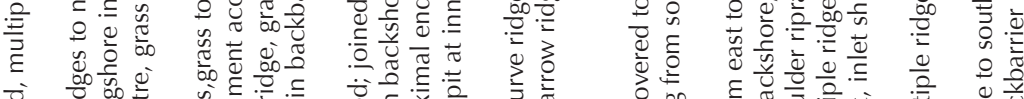

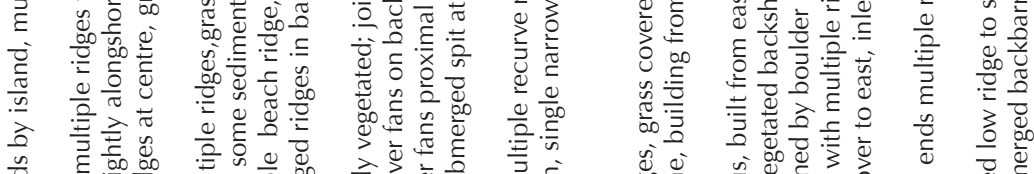

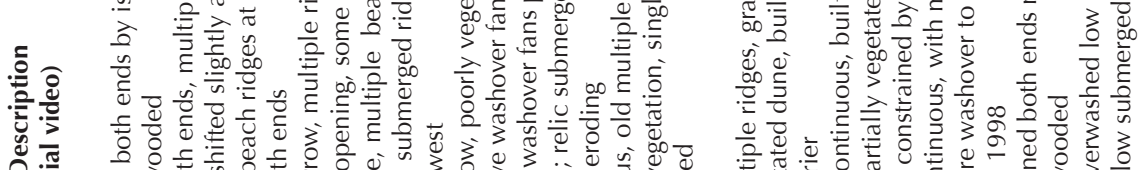
蛋

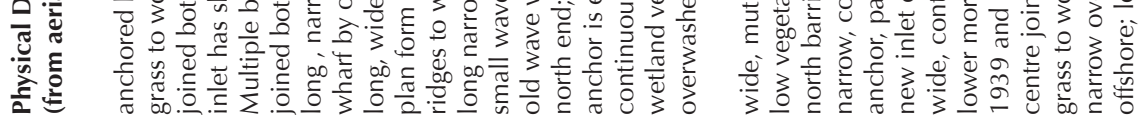

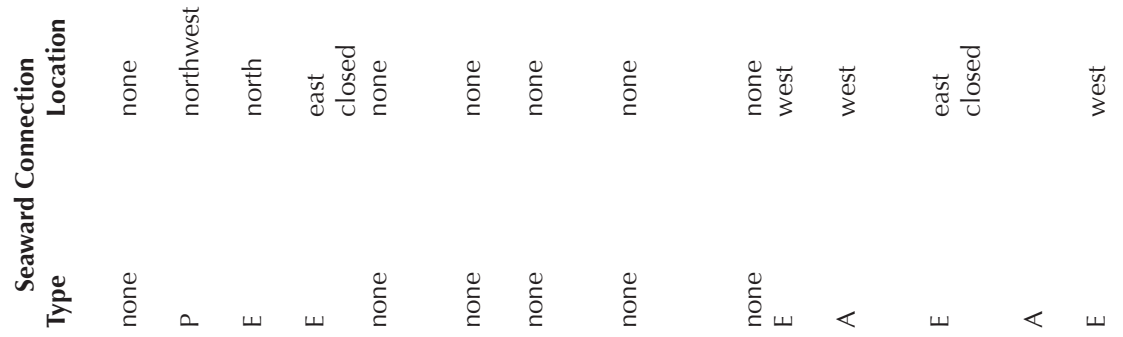

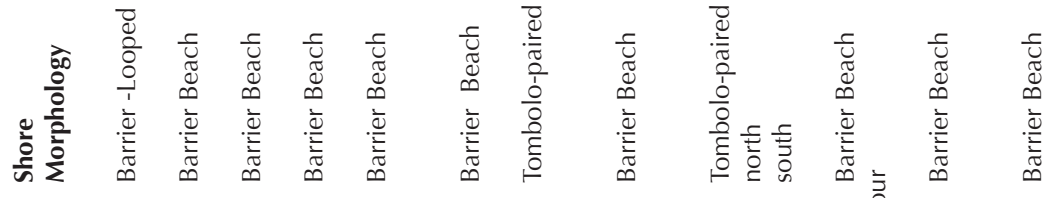

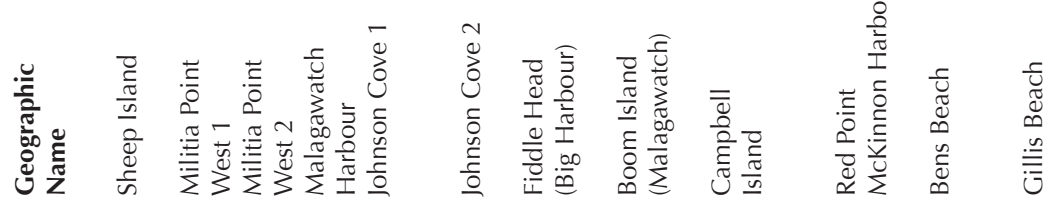

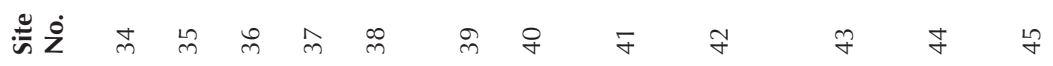


in.

당



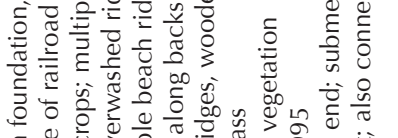

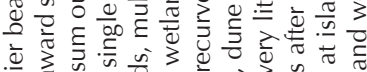

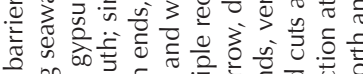

ᄃำ

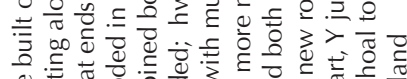

ป.

.0.

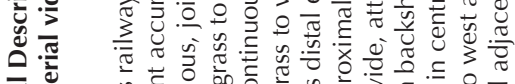

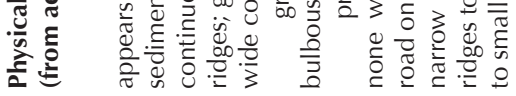

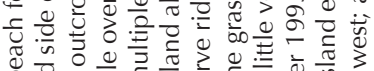

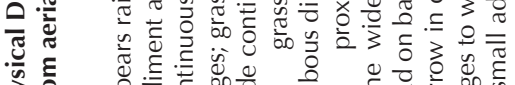

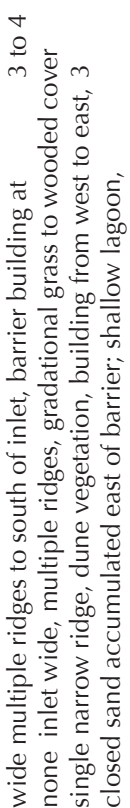

$+\quad \frac{0}{\frac{0}{0}} \stackrel{+}{\frac{\pi}{n}} \quad m \quad \ln m$

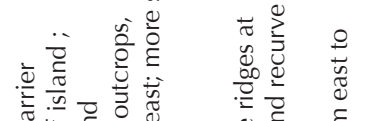

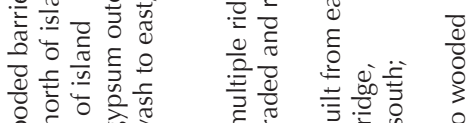

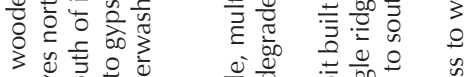

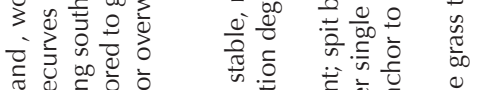

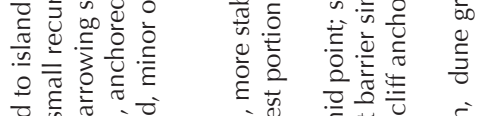

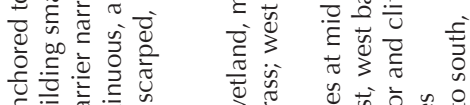



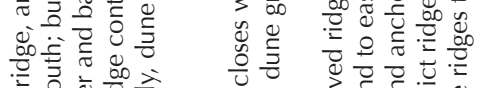

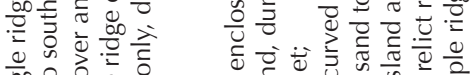
0.

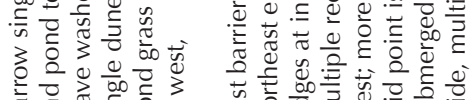

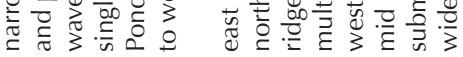

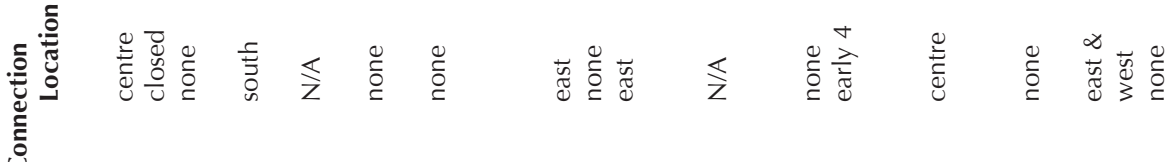

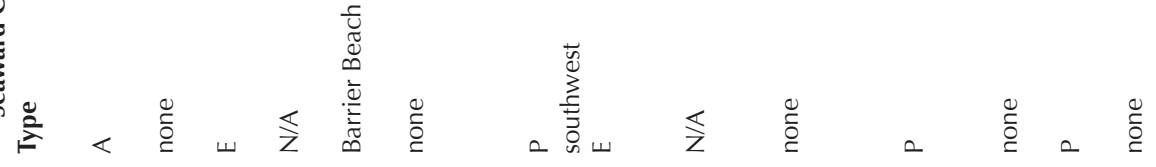

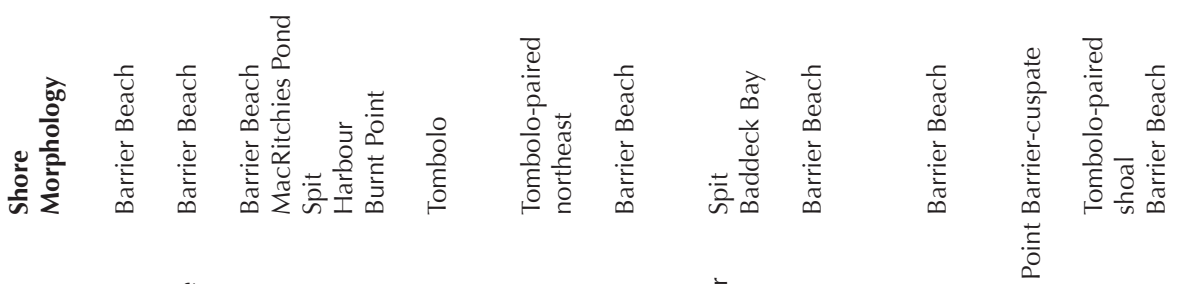

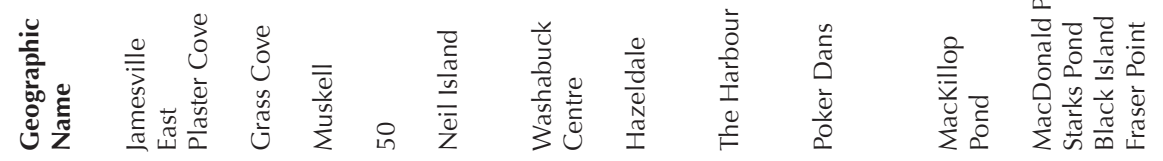

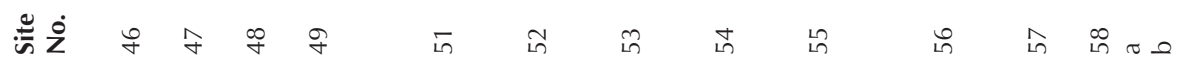




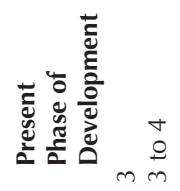

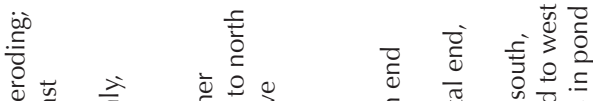

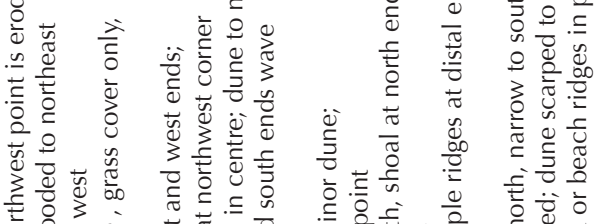

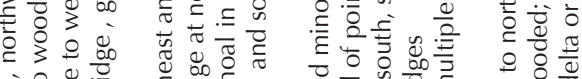

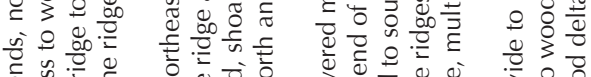

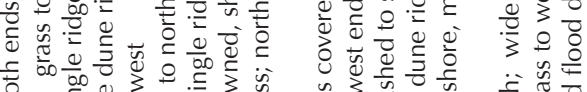
吉

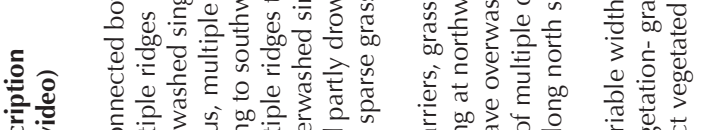
$\forall m \operatorname{Ln} \forall \quad+\quad n$

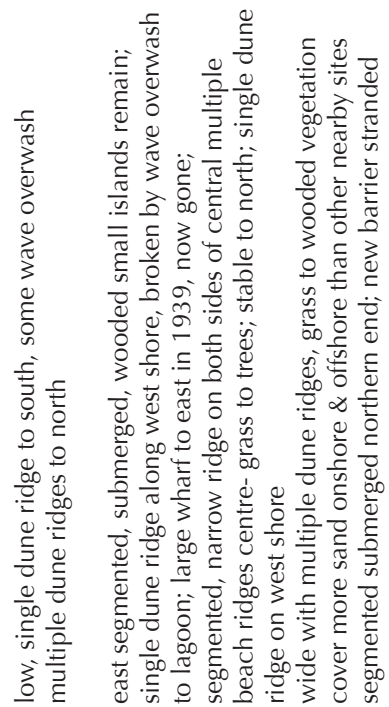

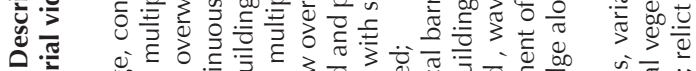

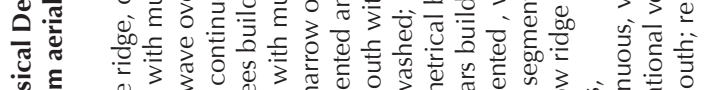

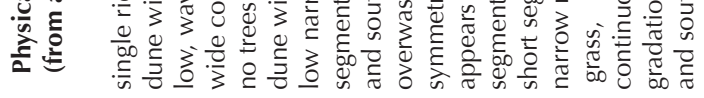

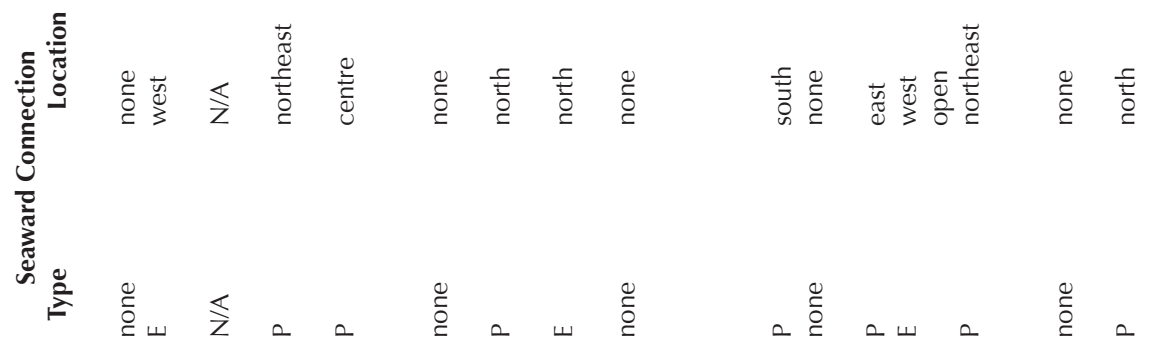

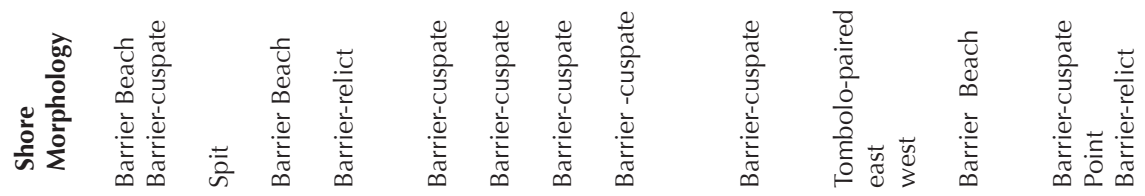

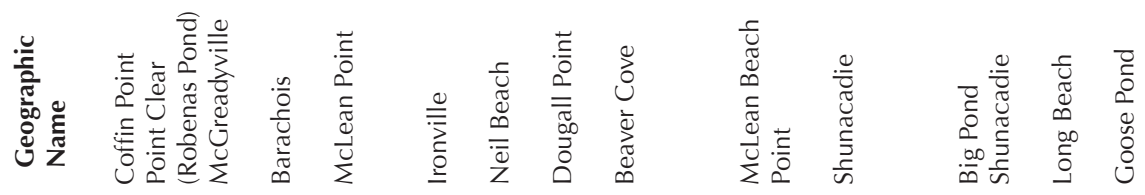
专之 


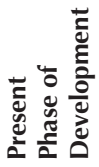
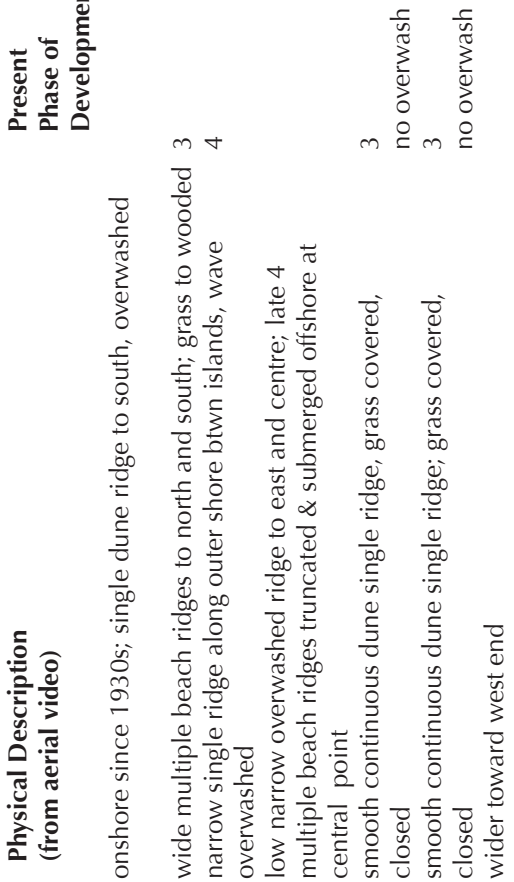

这

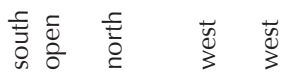

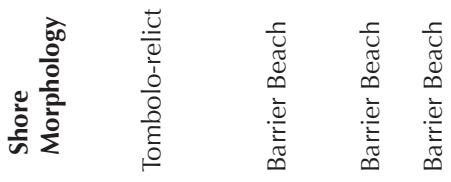

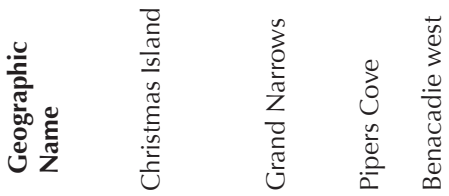

部 